\title{
Drug-induced dyskinesia in Parkinson's disease. Should success in clinical management be a function of improvement of motor repertoire rather than amplitude of dyskinesia?
}

\author{
Jean-François Daneault ${ }^{1,2}$, Benoit Carignan ${ }^{2,3}$, Abbas F Sadikot ${ }^{1}$, Michel Panisset ${ }^{4}$ and Christian Duval $^{2,5^{*}}$
}

\begin{abstract}
Background: Dyskinesia, a major complication in the treatment of Parkinson's disease (PD), can require prolonged monitoring and complex medical management.

Discussion: The current paper proposes a new way to view the management of dyskinesia in an integrated fashion. We suggest that dyskinesia be considered as a factor in a signal-to-noise ratio (SNR) equation where the signal is the voluntary movement and the noise is PD symptomatology, including dyskinesia. The goal of clinicians should be to ensure a high SNR in order to maintain or enhance the motor repertoire of patients. To understand why such an approach would be beneficial, we first review mechanisms of dyskinesia, as well as their impact on the quality of life of patients and on the health-care system. Theoretical and practical bases for the SNR approach are then discussed.
\end{abstract}

Summary: Clinicians should not only consider the level of motor symptomatology when assessing the efficacy of their treatment strategy, but also breadth of the motor repertoire available to patients.

Keywords: LID, DID, Levodopa, Deep brain stimulation, DBS, Treatment, Quality of life, Motor complication, Motor fluctuations, Algorithm

\section{Background}

Parkinson's disease (PD) is a progressive neurodegenerative disease characterized by a predominant loss of dopaminergic neurons in the substantia nigra pars compacta [1] leading to the development of motor symptoms. Four cardinal motor symptoms are associated with PD: tremor, muscle rigidity, postural instability and akinesia/bradykinesia [2]. PD is also associated with the development of non-motor symptoms stemming from the pathological involvement of particular brain structures and complex neurochemical imbalances [3]. These symptoms include psychiatric manifestations [4], rapid eye movement and other sleep disturbances [5,6], mood disturbance $[7,8]$, bradyphrenia and cognitive deficits [9-12], anosmia [13],

\footnotetext{
* Correspondence: duval.christian@uqam.ca

${ }^{2}$ Centre de Recherche de I'Institut Universitaire de Gériatrie de Montréal,

4545 Chemin Queen-Mary, Montréal, Québec, H3W 1W4, Canada

Full list of author information is available at the end of the article
}

fatigue, autonomic system dysfunction and pain [14]. Although both motor and non-motor symptoms can be disabling for patients, current treatments target predominantly the motor dysfunction using mainly dopaminergic therapies. Prolonged use of dopaminergic agents can lead to drug-induced dyskinesia.

Dyskinesia may have deleterious effects on the quality of life of both patients and their caregivers, and create an additional strain on the health-care system. While several approaches are taken by movement disorder specialists to delay or manage dyskinesia, neurologists not specialized in the treatment of movement disorders and general practitioners may find it difficult to control dyskinesia while maintaining clinically significant reductions in typical PD symptoms. In this paper, we propose a novel way to view the clinical management of dyskinesia, which could benefit patient care. In order to comprehend fully the complexity of the problem of dyskinesia, we first provide an overview 
of the treatments for PD and how they can induce dyskinesia. We then provide a review of the impact of dyskinesia on quality of life and health-care costs.

\section{Discussion}

\section{How prominent is the problem of PD?}

The prevalence rate of PD was estimated a few years ago to be between 100 to 200/100,000 population [15-19], with an incidence rate of 10 to $20 / 100,000$ population $[20,21]$. However, the number of PD cases is increasing and will have grown from 10 million worldwide in the late 1980s [22] to 40 million in 2020 [23] due mainly to the aging population. While most patients with PD are diagnosed after the age of 55 (see [24,25]), about $10 \%$ of patients are diagnosed before the age of forty [26,27] and characterized as 'young-onset PD' [22]. While most young-onset patients exhibit typical parkinsonian symptoms [28], they appear to display slower disease progression [25] and show a tendency for increased prevalence and severity of motor fluctuations and dyskinesia with prolonged $\mathrm{L}_{\mathrm{L}}$ 3,4-dihydroxyphenylalanine (L-DOPA) therapy [22,29-32]. Early onset of motor complications may be especially relevant in these patients as they will live with the disease for longer periods [33] with a diminished quality of life [34] and impaired social and economic productivity [34,35].

\section{What are the current treatments of PD?}

Based on the classical model of basal ganglia movement disorders [36-38], the loss of dopaminergic neurons associated with $\mathrm{PD}$ results in depletion of dopamine content into the neostriatum. This translates into altered basal ganglia neural activity, producing a change in the output of the basal ganglia-thalamo-cortical pathways. The cardinal hypokinetic symptoms of PD result from a change in the activity of thalamo-cortical inputs to motor cortical areas which impairs voluntary movement $[36,39,40]$. Consequently, the primary goal of PD treatment is to counteract the depletion of dopamine. Since dopamine causes severe nausea, and cannot easily cross the blood brain barrier, other means of counteracting this dopaminergic deficiency have been developed (see [41] and [42] for comprehensive reviews of current treatment options). In brief, the current gold standard for the treatment of PD motor symptoms is L-DOPA [24,25,41,43-46] associated with a decarboxylase inhibitor such as carbidopa [47-49]. Over the years, several compounds were developed to be used as adjuncts to L-DOPA or as replacement therapy. Catechol-O-methyltransferase (COMT) inhibitors such as entacapone and tolcapone are used as adjuncts to L-DOPA in order to enhance its bioavailability [26,50,51]. Monoamine oxidase-B (MAO-B) inhibitors, on the other hand, are used to extend the duration of action of L-DOPA by decreasing the metabolic degradation of dopamine in the synaptic cleft $[1,22,29$, 46,52-55]. Another class of drugs that can be used as an adjunct or replacement to L-DOPA is dopamine agonists as they bind to dopaminergic receptors, mimicking the action of dopamine. They were initially used to reduce the dose of L-DOPA to control motor complications [24,41] and may be considered for initial monotherapy [56,57], especially in younger patients to delay the onset of dyskinesia.

While medications are the main therapeutic avenue for the alleviation of PD symptoms, surgical procedures can also provide symptomatic relief in some patients. Ablative surgeries have been used in the treatment of motor dysfunction in PD for several decades and can be very effective [58]. Several nuclei of the basal gangliathalamo-cortical pathways are targeted using this technique, such as the thalamus [58-69], the globus pallidus internus (GPi) [70-80] and the subthalamic nucleus (STN) [76,81-90]. More recently, deep brain stimulation (DBS) has become an invaluable clinical management tool for medically intractable motor symptoms. Interestingly, DBS targets the same structures that are targeted in ablative surgeries [91]. DBS therapy has the advantage that it is reversible and can be titrated but it suffers from complications and inconveniences related to prosthetic implants [92-98]. In recent years, STN and GPi DBS [95,99-109] have become the targets of choice for effective relief of many motor symptoms associated with PD, including marked reduction of dyskinesia [110,111]. Other structures were recently investigated for the alleviation of specific symptoms [112]. For example, the pedonculopontine nucleus (PPN) [113-116] was targeted for DBS in patients with gait and postural imbalance issues. The centro-median-parafascicular (CM/Pf) complex [117] and the zona incerta [118-121], on the other hand, were targeted in patients with tremor, as an alternative to the well-established thalamic ventrolateral (VL) nucleus. However, whether DBS within these alternative structures has an impact on dyskinesia has yet to be assessed.

Novel and experimental treatments of motor symptoms of $\mathrm{PD}$, some of which are potentially disease-modifying, have also been introduced. One promising avenue is the development of novel drugs for the treatment of PD symptoms. For instance, Adenosine $\mathrm{A}_{2 \mathrm{~A}}$-receptor antagonists offer the potential to provide benefits that are not delivered by traditional dopaminergic medications and might avoid dopaminergic side effects through a reduction of the over-activity in the striatopallidal pathway [122]. Many of these drugs are currently in development and are at different phases of clinical trials. Prodrugs are another class of medication currently under development. They are inactive or poorly active compounds that undergo in vivo chemical or enzymatic activation that transforms them into 
an active drug [123]. They have better pharmacokinetic and pharmacodynamic properties than active drugs, thus having the potential of improved oral absorption, stability and passage of the blood brain barrier. For instance, different prodrugs are under development for dopamine, dopamine receptor agonists, better use of the endogenous transport systems of the blood brain barrier as well as different peptide and glutamatergic transport systems [124]. Cell transplant approaches for PD have been considered for several decades with equivocal initial results, especially when compared to currently available treatments. However, recent work has highlighted the potential of this treatment for dopaminergic neuron replacement [125-127]. Finally, there are many potential uses for gene therapy in PD. For example, it can be used to promote the expression of agents which cannot cross the blood-brain barrier, such as neurotrophins [128-131]. Preclinical models using neurotrophic factors provided promising neuroprotective or neuroregenerative outcomes, but initial trials in humans have been mainly disappointing. Gene therapy can also be used to modify the inherent properties of neurons within specific anatomical structures. For example, gene therapy was used to modify the phenotype of STN neurons from predominantly excitatory to predominantly inhibitory in order to restore balance within the basal ganglia-thalamo-cortical network [132-134]. While these are all promising treatments for PD, much work is required with regard to therapy and side effects prior to clinical application to larger patient groups. Relevant to the present paper, it is mainly unknown whether these emerging therapies may delay, treat or worsen dyskinesia.

\section{What are the main issues with current treatments?}

Long-term use of dopamimetic agents, in combination with continued dopaminergic denervation, can generate dyskinesia. Indeed, while dyskinesia are mainly associated with functional alterations within the basal ganglia pathways related to prolonged exposure to L-DOPA, dopamine agonists and DBS can also cause the appearance of dyskinesia [135-138]. The exact mechanism underlying dopamine agonist- or DBS-induced dyskinesia is still under investigation, but it is believed to stem from maladaptive mechanisms related to dopaminergic and glutamatergic systems (see [135] for review). Patients receiving intra-striatal dopaminergic neural grafts can also experience dyskinesia, also without the presence of exogenous dopaminergic agents (off-dyskinesia), possibly due to inappropriate responses to dopamine release by grafted neurons [126,139-141].

There are several different classifications or types of dyskinesia, such as dystonic, ballistic, choreic and myoclonic, which can be monophasic or bi-phasic [142-145], occurring at different times in relation to administration of dopaminergic medication. The most common dyskinesia remain the monophasic choreic type, which are involuntary movements that occur at peak-dose and are considered to be purposeless, non-rhythmic, abrupt, rapid, irregular and un-sustained [143]. We have recently provided the first characterization of the movement patterns of monophasic choreic dyskinesia based on quantitative measures of whole-body movements which highlight their complexity, and variability in amplitude and location over short periods of time [146-150]. This might explain the relative difficulty of patients to control or compensate for their dyskinesia while attempting to either plan or execute everyday motor activities.

Several risk factors are associated with the occurrence of dyskinesia including age of onset of PD [151-154], body weight $[155,156]$, disease duration $[157,158]$, and the level of exposure to L-DOPA $[153,159,160]$. A necessary factor in the development of dyskinesia appears to be the combination of dopaminergic denervation and long-term exposure to dopamine replacement therapy that promotes changes in the receptor environment and results in an altered clinical response to dopamine [161-164]. Under physiological conditions, striatal and synaptic dopamine levels are maintained at a relatively constant level [165]. The dopaminergic denervation observed in $\mathrm{PD}$, in association with the administration of L-DOPA at intervals during the day, induces oscillations in the concentration of striatal and synaptic dopamine levels $[166,167]$. This pulsatile stimulation of dopaminergic receptor is associated with functional changes within the basal ganglia $[168,169]$, which results in altered neural activity in the basal ganglia, thalamus and cerebral cortex [115] with associated involuntary movements.

Several fundamental functional alterations in the synaptic environment of the striatum are associated with development of dyskinesia. Dopaminergic denervationinduced pre-synaptic modifications occur at the cellular level which hinders dopamine homeostasis [153,170-172]. In addition, morphological and functional alterations occur in serotoninergic neurons, which may be a homeostatic attempt to counteract the dysregulation in dopamine levels [173]. Changes also occur at the postsynaptic level where dopamine receptor trafficking $[158,174]$, signalling [157] and sensitivity [161,175] are all altered in dyskinetic PD patients. Furthermore, Nmethyl-D-aspartate (NMDA), $\alpha$-amino-3-hydroxy-5methyl-4-isoxazolepropionic acid (AMPA) [151,152,176, 177] as well as metabotropic glutamate receptors [178-181] have been implicated in the maladaptive plasticity associated with dyskinesia (see [135] for review). While the definite mechanisms behind their relative involvement remain to be determined, these receptors are currently being investigated as potential targets for the management of dyskinesia.

Aside from these pre- and post-synaptic changes, other functional and structural changes also play a role 
in the pathogenesis of dyskinesia. Astrocytes modulate the expression of vascular endothelial growth factor [182], resulting in microvascular remodelling which may be an integral part of the changes in the neural environment that lead to dyskinesia. Over-activity of adenosine $\mathrm{A}_{2 \mathrm{~A}}$ receptors may also play a role in the generation of dyskinesia [183-188] through facilitation of the striatopallidal pathway [189]. Additionally, modified extracellular concentrations of glutamate [190-193] as well as an altered expression of glutamate transporter genes [191,194,195] have been observed in different basal ganglia structures when dyskinesia are present. Finally, recent studies suggested that degeneration of inter-hemispheric striatal mechanisms may play a significant role in the genesis of dyskinesia through yet undefined mechanisms [196,197]. Taken together, these functional alterations point towards a complex multi-factorial mechanism behind the generation and expression of dyskinesia which could explain why the management of those motor complications is so problematic.

\section{Why is managing dyskinesia as much art as science?}

Due to the complex pathophysiology of dyskinesia, there has been considerable debate about which treatment is more efficacious for best symptom management while still avoiding motor complications [28,32-34,40,44,47,48,51, 52,198-201]. Several studies examined the incidence of dyskinesia with different medication (see [41] for an extensive review). Here, we focus on possible treatment options when dyskinesia have already occurred. The primary option for clinicians is to reduce medication dosage; however, this can lead to the resurgence of typical parkinsonian symptoms. The second option is to fragment dosage, reducing each dose and increasing its frequency for more constant delivery as the pulsatile delivery of L-DOPA is, in part, responsible for the observed functional alterations within the basal ganglia. The use of controlled-release oral medication may limit this pulsatile effect [202]. However, the efficacy of such controlled release drugs in treating dyskinesia is investigational at best and there is little evidence to suggest that they may delay the onset of dyskinesia [41]. Nonetheless, the concept behind controlledrelease formulations, that is, a more continuous delivery of medication rather than a pulsatile increase in medication normally observed with PD medication, has spurred the development of continuous drug delivery (CDD) systems such as mini-pump guided continuous apomorphine infusion [203], duodenal L-DOPA infusion (Duodopa) $[30,201]$, and transdermal delivery of rotigotine (dopamine agonist) through a patch [204]. Several continuous drug delivery treatments are proposed as useful in reducing the incidence or treatment of dyskinesia [203,205-207], but there is insufficient evidence to characterize them as unequivocally effective [41]. For example, a study on an animal model of PD demonstrated that continuous delivery of rotigotine did not induce dyskinesia and functional sensitization, whereas using an oral formulation at different intervals did [208]. On the other hand, a pilot study on duodenal infusion of L-DOPA was shown to induce similar levels of dyskinesia as pulsatile delivery systems; however, once dyskinesia are present, switching to duodenal L-DOPA reduces the duration of dyskinesia [209]. This highlights the variability in the effectiveness of these treatments. Furthermore, these approaches to dyskinesia treatment are limited due to the complexity of the procedure and the difficult long-term management of patients. Indeed, the invasive nature of some of these treatments limits the number of potential candidates; and the potential for severe complications requires adequate monitoring. Another option is to control dyskinesia by reducing the L-DOPA dose and introducing dopamine agonists. Again, this option is not without problems, including the lower efficacy of dopamine agonists in treating motor symptoms [210-213], as well as increasing the incidence of other disabling side effects such as somnolence, sleep attacks, dizziness, nausea, delusions, impulse control disorders, hallucinations and confusion [214,215]. In addition, one must keep in mind that some studies have observed the appearance of dyskinesia with the use of dopamine agonists without the concomitant presence of L-DOPA [213].

There are currently very limited direct drug treatments for dyskinesia as only two medications were shown to be efficacious: amantadine and clozapine [41]. Amantadine is a NMDA receptor antagonist [216] that was shown to reduce significantly the duration and severity of dyskinesia in several studies [216-218]. However, its mechanism of action leading to reduction in dyskinesia has yet to be conclusively determined. Clozapine is a high affinity serotoninergic agonist as well as a low affinity dopamine agonist [219-221]. One study demonstrated the ability of clozapine to reduce dyskinesia significantly [222]. However, the severe side effects associated with clozapine, such as agranulocytosis [223], central nervous system depression, seizures, dementia, and myocarditis [224], limit its use in clinical practice as it requires strict monitoring.

Surgical interventions can also reduce dyskinesia in a subset of patients as both STN and GPi DBS were shown to reduce dyskinesia effectively $[103,109]$. One possible mechanism behind the reduction in dyskinesia is reduction in medication dose following surgical treatment [225]. However, the end result is highly dependent on several factors such as lead placement, stimulation parameters and level of reduction in medications. Another surgical intervention that has demonstrated a reduction in dyskinesia is pallidotomy $[73,74,226]$. In fact, this intervention was shown to be as effective as STN DBS for the reduction of dyskinesia [74]. Again, the outcome of this procedure is greatly dependent on lesion extent and location. 
Future avenues for drug treatment of dyskinesia include the development of adenosine $\mathrm{A}_{2 \mathrm{~A}}$ receptor antagonists $[227,228]$ as well as the use of metabotropic glutamate receptor 5 (mGluR5) antagonists [229] and orthosteric metabotropic glutamate receptor 4 (mGluR4) agonists [230]. While these compounds are currently in different testing phases, a few studies using adenosine $\mathrm{A}_{2 \mathrm{~A}}$ receptor antagonists and mGluR5 antagonists have demonstrated a significant reduction in dyskinesia induction in animal models $[183,186,231]$ and subgroups of human samples $[227,229,232]$. On the other hand, orthosteric mGluR4 agonists are only beginning to be studied for their effect on the indirect pathway of the basal ganglia.

Maintaining therapeutic efficacy while at the same time trying to control dyskinesia can be difficult with all treatments for PD. Clinicians often progressively introduce an intricate combination of medications that could help re-establish neurotransmitter balance and avoid motor fluctuations. Unfortunately, the unavoidable dopaminergic denervation and receptor imbalances render this task increasingly difficult as the disease progresses.

\section{How prominent is the problem of dyskinesia and its management?}

The incidence of dyskinesia is estimated at $30 \%$ to $50 \%$ after five years of initiating L-DOPA treatment [142,198]. As the disease progresses, the incidence can increase to $60 \%$ to $100 \%$ after 10 years $[65,198,211,233,234]$. These figures are even higher in young-onset PD where it is observed that almost all patients experience dyskinesia after only six years of treatment [22]. Once these motor fluctuations occur, increased monitoring of patients is required. However, the lack of movement disorders specialists able to handle such complex side effects of medication hinders proper monitoring of these patients. In the United States, the ratio of neurologists varies drastically between regions ranging from a low of 1 and a high of $11 / 100000$ population [235] with an average close to $5 / 100000$ population [236]. In Canada, in 2008, the number of neurologists varied between 0 and 3/100 000 population in different regions of a geographically vast country [237]. While most European countries fare relatively well with an average of 5 neurologists per 100000 population [236], Asia, where the majority of the world's population resides and where the expected number of $\mathrm{PD}$ cases is expected to grow several fold in upcoming years [238], is in dire need of neurologists with less than 1/100 000 population [236]. Of note is that these figures encompass all neurologists; the number of movement disorders specialists, who possess the necessary tools to adequately manage the symptoms of PD and motor complications associated with their treatment, is much lower, and to our knowledge, has never been evaluated. Another issue facing patients with motor fluctuations is that most movement disorders specialists are located in larger cities; thus forcing patients from remote communities to travel great distances for medical consultations and follow-ups. These issues may explain why only $45 \%$ of patients with PD in Ontario (Canada) have access to a specialist at least once a year [239]. The lack of access to trained clinicians has a negative impact on patient care since constant management of medication is required to delay or negate the undesired motor fluctuations.

\section{What would be the impact of better management of dyskinesia on quality of life?}

The ability to engage and maintain social interactions is inevitably linked to the ability to interact with the physical environment and, as such, is associated on the level of independence of patients. In patients with PD, reduced participation in social activities appears in part related to loss of mobility and impairs quality of life [240,241]. This phenomenon is later exacerbated due to disease progression and complications related to treatments [242,243]. However, the actual impact of dyskinesia on quality of life is still controversial. Some researchers have suggested that dyskinesia have only a moderate impact on quality of life of patients [198,244-246]. One study even observed an improvement in quality of life in PD patients with dyskinesia [244]. Another recent study demonstrated that 'Patients with PD experiencing dyskinesia are less likely to be concerned about dyskinesia and more likely to prefer dyskinesia over parkinsonian symptoms compared to patients without dyskinesia' [247]. This may be explained by the patient's own perspective on the impact of dyskinesia on his/her motor repertoire, that is, the movements a particular patient deems important for his/her quality of life. Of course, if dyskinesia have a moderate impact on the motor repertoire, it is likely that he/she will not consider dyskinesia as problematic. Patients would rather be able to perform their activities than be constricted by their parkinsonian symptoms. However, such findings must be interpreted carefully, in light of recent evidence showing that dyskinetic patients may suffer from anosognosia, that is unawareness of deficits associated with an illness [248]. Accordingly, even if they do not complain about their involuntary movements, dyskinesia may still have a deleterious effect on their motor repertoire. As such, mild dyskinesia themselves may not be problematic, but more severe forms may reduce quality of life by impacting on the patients' motor repertoire.

In fact, other studies showed that the presence of dyskinesia is a key factor in determining the quality of life of patients [249-251], especially in young patients who participate in the workforce. Studies showed that the main dimensions of quality of life that are affected by dyskinesia are psychological, social [252,253] and stigma [253-255]. This may be the result of loss in mobility, 
increased falls [256], weight loss [156] and even modifications of motor behavior in the OFF state [257]. Other studies demonstrated that the reduction in quality of life of PD patients with dyskinesia [258-260] could also be a result of higher levels of anxiety [261-264] and depression[260], more so than in patients without dyskinesia. However, in the study of Montel et al. [253], the only factor that had a significant impact on quality of life was the presence of dyskinesia, not neuropsychiatric manifestations. This indicates that dyskinesia can affect patient quality of life directly and also by inducing, or at least modulating the level of different neuropsychiatric disorders.

The impact of dyskinesia on the quality of life of PD patients can also be evaluated by assessing the effectiveness of interventions aimed at controlling dyskinesia on quality of life. For instance, a recent study demonstrated that PD patients had a significant improvement in quality of life after 18 months of continuous intra-duodenal L-DOPA infusion [265]. Interestingly, they did not observe a significant change in 'ON medication' motor symptomatology after treatment but did observe a significant reduction in dyskinesia. As such, the reduction in dyskinesia may have played a role in the improvement of quality of life. Similar results were obtained in patients undergoing GPi DBS where the reduction in dyskinesia scores was highly correlated with the improvement in overall quality of life [266]. While these are merely two examples of studies using quality of life as primary or secondary endpoints to assess the impact of different interventions, it is becoming more common to use quality of life to evaluate therapeutic effectiveness.

Another issue to consider is that dyskinesia also impact upon on the quality of life of patients' primary caregivers (for example, spouses). Indeed, as the disease progresses and patients with PD begin dealing with a loss of independence, the quality of life of their caregiver also degrades as they are more prone to social isolation, psychological problems, such as depression, and physical issues [267-270]. This is evident through the results of McCabe et al. [271] where PD patients and caregivers only differed in physicaland psychological-related quality of life. Social interaction and environmental quality of life scores were not significantly different [271]. These issues become more prominent with disease progression when motor complications, such as dyskinesia, are apparent [272]. Importantly, it has been demonstrated that psychosocial factors such as social support are critically important to the caregivers' quality of life [273]. As health-care systems are over-extended and promote the implementation of community care programs as a means of alleviating pressure on the system, the capacity of caregivers to provide support becomes essential [274]. If caregiver burden is excessive, it may reduce the quality of the care patients require [273]. As such, it is important to acknowledge and find ways to optimize the caregivers' quality of life.

\section{What would be the impact of better management of dyskinesia on the health-care system?}

As the disease progresses, so does the burden on patients and the health community $[83,275]$. Studies have demonstrated the immense effect of dyskinesia on the costs of treating PD patients. For instance, a European study showed that the average cost per annum for the treatment of PD patients without dyskinesia was $€ 11,412$, but it more than doubled to $€ 24,990$ in patients with severe dyskinesia [260]. This increase in treatment cost was accounted for by both non-medical expenditures, such as community services and unpaid help provided by the caregiver, and medical expenditures related to medication and hospitalization due to more complex and expensive treatment regimens [260]. A French study also demonstrated that the presence of dyskinesia more than doubled treatment costs and increased medical visits [276]. They also observed that the severity of dyskinesia increased medical costs by increasing the need for caregivers. This led them to estimate the total annual medical cost of dyskinesia in France to be between 588 and 812 million francs [276]. Furthermore, a recent study from the United States showed that dyskinesia resulted in an increase in total treatment costs by $29 \%$, and PD-related treatment costs by $78 \%$ compared to costs incurred by PD patients without dyskinesia [277]. This translates into an increase of $\$ 5,549$ in the year following the first appearance of dyskinesia when compared to PD patients without dyskinesia. The majority of this amount was related to an increase in PD-related costs of $\$ 4,456$ in patients with dyskinesia; not to costs associated with co-mobidities [277].

A major problem is that these direct costs have to be added to the already increased health-related expenditures associated with having PD compared to healthy aging [278]. In Canada, the annual direct costs related to PD were estimated at $\$ 202$ million, which includes hospital (44\%), drugs (49\%) and physician consultations (7\%). Indirect costs associated with mortality (38\%) and morbidity (62\%) were estimated at $\$ 245$ million, for a total of approximately $\$ 447$ million [278]. Interestingly, a great proportion of indirect costs are related to early retirement. The direct health-care cost of PD in the United States was estimated at $\$ 10,349$ per patient per year [279]. Combining these direct costs with estimates of indirect costs, the total costs of PD in the United States may be as high as $\$ 23$ billion annually [279]. If we consider that the number of persons 65 years of age and older is expected to increase significantly over the upcoming years, the cost of treating PD patients is likely to exceed $\$ 50$ billion annually in the United States by 
2040 [279]. In China, the problem is even greater because of the larger number of patients. In 2004, it was estimated that the yearly health-care cost was about $\$ 925$ per patient, which represents half of the mean individual annual income [280], for a total of $\$ 1.57$ billion annually. The total cost correlated significantly with disease severity and the frequency of outpatient visits [280]. It is clear that better patient management is required and one approach is to develop and implement evidence-based practice. The question then becomes if the reduction of dyskinesia incidence and severity can modulate the costs. A recent study examined the effectiveness (time to levodopa and time to levodopa-induced dyskinesia), cost, and quality-adjusted life-years in two trials of dopamine agonists. They showed that rasagiline delayed the onset of dyskinesia by $10 \%$ and reduced costs by $18 \%$ per patient over five years [281]. Furthermore, a French study estimated that each $10 \%$ of reduction in OFF periods would result in a $5 \%$ reduction of direct medical costs [282]. These studies demonstrate that finding approaches to control either the incidence or the severity of dyskinesia and other motor fluctuations should be developed and implemented in order to reduce the burden on the health-care system.

\section{What is the theory behind our proposed approach to the treatment of dyskinesia?}

Evidence-based practice aims to apply the best available evidence from scientific investigations to clinical decision making. To apply evidence-based practice for the management of dyskinesia, information about the influence of dyskinesia on voluntary movements must be known so as to understand the challenges facing patients when planning and executing movements from their motor repertoire. It is important to discriminate between activities of daily living and motor repertoire of patients as activities of daily living are essential for minimal functional independence while the motor repertoire encompasses all movements deemed important for a good quality of life for a specific patient. As such, the motor repertoire will be personalized and will vary greatly depending on the movements patients wish to perform on a regular basis. Finally, it is important to assess whether other symptoms are concomitantly present with dyskinesia; which may in fact be responsible for motor deficits. To date, several algorithms have been proposed to manage dyskinesia [283,284]. Interestingly, these algorithms are geared towards markedly reducing or eliminating dyskinesia, without necessarily taking into account how the proposed strategy affects the motor repertoire of patients. This is important since some patients may rather have mild dyskinesia then undergo the process of medication change, especially if dyskinesia do not hinder their motor repertoire. Indeed, the reduction in dyskinesia through either a reduction in medication dosage or a change in medication could lead to a resurgence of typical hypo- or hyper-kinetic parkinsonian symptoms impeding the patient's voluntary motor behaviors and hence reduce his quality of life for that specific period. The clinician will judge whether the reduction in dyskinesia following treatment regimen modification based on these algorithms is clinically satisfactory. For this, clinicians rely mostly on their experience and patient feedback. They can also use clinical scales [285-288] to assess the amplitude of dyskinesia and their impact on activities of daily living. However, current scales only provide a general sense of the amplitude of dyskinesia and their impact. Most do not measure the impact of the amplitude of dyskinesia on voluntary movements and certainly not on the entire motor repertoire of patients. In fact, a recent review of the different scales for the assessment of dyskinesia found that of the eight scales used in $\mathrm{PD}$, only two were recommended for use (that is, the Abnormal Involuntary Movement Scale (AIMS), and the Rush Dyskinesia scale) [288]. The AIMS assesses the amplitude of dyskinesia in each limb whereas the Rush also incorporates a section on the impact of dyskinesia on certain activities of daily living such as putting on a coat. A recent scale, the PDYS-26, a patient-based questionnaire, focuses solely on the impact of dyskinesia on activities of daily living [289]. One main issue of these scales is that they cannot segregate the impact of dyskinesia and cardinal symptoms of PD on the performance of motor behaviors. Another point that requires attention is that, as mentioned above, activities of daily living do not circumscribe the whole motor repertoire deemed necessary by each patient; they merely represent general tasks that provide some functional independence. For example, a patient who is an artist painter with low amplitude dyskinesia may deem that his/her dyskinesia are devastating, while most daily living activities are actually intact (that is, he can put on a coat, cut his food and dress himself but, he cannot perform the fine voluntary movements required for him to paint a canvas). Then, one could legitimately ask the following question: how does the amplitude of dyskinesia relate to its impact on voluntary movements performed in daily life? The opposite could also be true. A patient with high levels of dyskinesia may judge that his/her involuntary movements are not an issue since they prefer to be dyskinetic rather than OFF, as proposed in a recent paper [247].

We propose that the evaluation of the impact of dyskinesia be viewed as a function of a signal-to-noise ratio (SNR). The concept of the SNR is based on the fact that success of voluntary movements (the motor output) is directly correlated to the magnitude of the intended voluntary movement (the signal) and inversely correlated with the magnitude of the involuntary movement (the noise) in the motor stream [290-297]. In other words, the 
likelihood of success in performing voluntary movements is not only dependent on the magnitude of the symptoms present, but also dependent on the type of movement performed by the patients. Such an analysis would make it possible to determine the motor repertoire available to patients based on the magnitude of symptoms. For instance, if a patient presents only with tremor, the SNR could be represented by equation 1 :

$\frac{\text { [Voluntary drive for a specific movement }]}{[\text { Tremor }]}=$ Motor output

Here, tremor would become deleterious only if the intended movement is below a threshold that will allow tremor to be close to, or supersede, the voluntary movement in amplitude. It could also be deleterious if the frequency of the intended movement is close to the frequency of that tremor [298-300]. Of course, this is an oversimplification as PD patients rarely exhibit only one motor symptom. Therefore, a more accurate representation of the SNR observed in PD patients would be equation 2:

$$
\frac{[\text { Voluntary drive for a specific movement }]}{[\text { Tremor }]+[\text { Bradykinesia }]+[\text { Rigidity }]+[\text { Postural Instability }]}=\text { Motor output }
$$

Here, the noise would be the sum of all cardinal motor symptoms, regardless of their neural origin. Indeed, bradykinesia could be caused by bradyphrenia during complex decision making, rather than a lack of cortical activation by thalamo-cortical pathways. Interestingly, as the disease progresses and motor complications arise, more 'noise' parameters could be added to equation 2 such that dyskinesia could be taken into account (equation 3):

$$
\frac{[\text { Voluntary drive for a specific movement }]}{[\text { Tremor }]+[\text { Bradykinesia }]+[\text { Rigidity }]+[\text { Postural Instability }]+[\text { Dyskinesia }]}=\text { Motor output }
$$

Success for a particular task would be predicated upon the ratio between the amplitude of the intended movement (the signal; the numerator) and the magnitude of symptoms (noise; the denominator) (see Figure 1).

This relationship between voluntary and involuntary movements was demonstrated by us in previous work [290-297]. For instance, we showed that during slow alternating movements at the wrist, tremor was detected [295], and its amplitude was directly correlated with deficits of accuracy [294]. During fast movement, tremor was undetected, and its amplitude previously assessed in the postural condition was unrelated to performance [294,297]. Furthermore, we showed that ventro-lateral thalamotomy $[59,61,294]$ had no impact on fast movements, but increased the SNR by removing tremor, hence improving tremendously the accuracy during slow movements [294]. We also showed that in tasks where the voluntary movement was performed with varying amplitude and velocity, the faster sections presented with higher SNR, and there was a reduction in deviation from the intended trajectory of the movement $[294,295]$. Accordingly, the amplitude of velocity of the intended movement seemed to be important in determining the impact of involuntary movements on voluntary motor acts. This concept relates to Fitts law [301], which proposes that two movements having the same amplitude may possess different velocity profiles, depending on the difficulty (target size) of the task. For example, bringing a glass of water to the mouth may have the same amplitude as bringing a spoon full of soup, but the velocity will not be the same because of the increased difficulty associated with keeping the soup in the spoon. As such, in order to properly assess the complexity of a voluntary movement, both its amplitude and velocity must be examined. In patients where whole-body peak-dose dyskinesia were recorded simultaneously with voluntary movements (same tasks as above), we found that during fast hand movements, dyskinesia were not visible [296]. Interestingly, patients with dyskinesia presented with levels of bradykinesia similar to those of PD patients without dyskinesia [296]. We also found no relationship between the level of dyskinesia and accuracy during slow movements [293], indicating that dyskinesia may not have been the primary source of error during movements that required accuracy. This strongly supports the concept that 'noise' is not limited to visible involuntary movements, but may also include other symptoms such as rigidity or bradykinesia [291] as proposed in equations 2 and 3. In the aforementioned study, patients had little or no clinicallydetectable rigidity, so bradykinesia was probably the main cause of reduction in motor performance. Taken together, this illustrates that different types of noise observed in PD can be independent from each other at the neurophysiological level but can each contribute to the performance of a given task. In another study, we demonstrated that patients with Huntington's disease presenting with chorea were not impaired during fast hand movements. However, they presented with large errors during slow manual tracking, which correlated with the amplitude of chorea. This illustrates again that involuntary movements can be of no consequence when the SNR is large enough. This also indicates that the SNR concept could be applied to pathologies other than PD.

The aforementioned data on PD fits well with issues facing clinicians. Indeed, any reduction in dyskinesia levels could lead to increased typical parkinsonian motor symptoms. Accordingly, clinicians may be replacing one kind of noise with another one (this concept is illustrated in Figure 2).

To better illustrate this theory, we present below two hypothetical situations that could be encountered in clinical practice (Figure 2). 


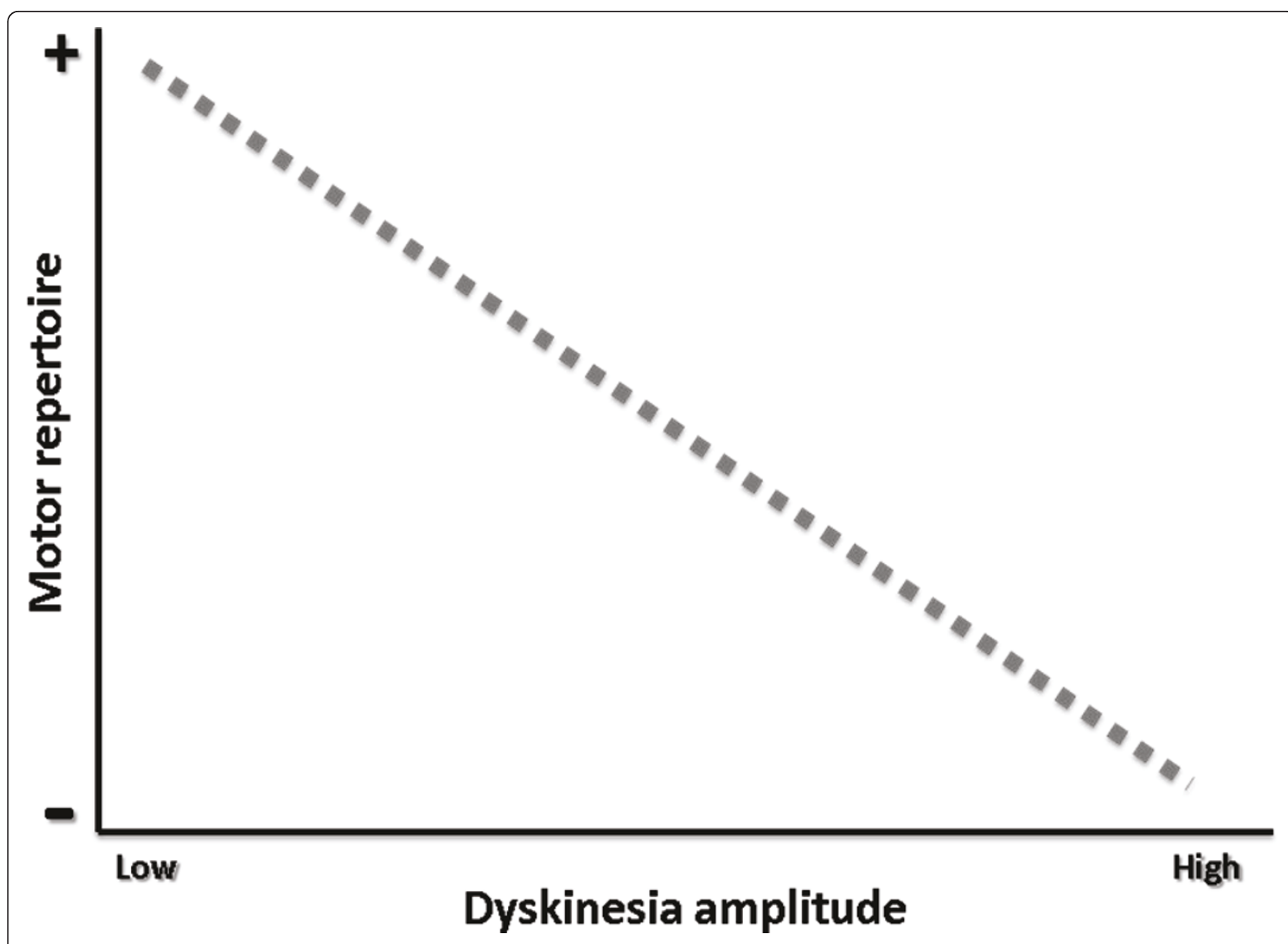

Figure 1 Shown here is the theoretical relationship between the amplitude of involuntary movements (dyskinesia) and the motor repertoire of patients. We hypothesize that higher amplitudes of dyskinesia will result in lower signal-to-noise ratio (SNR; dashed line) and, therefore, a loss of motor repertoire.

Situation 1: the clinician reduces L-DOPA or dopamine agonist dosage and the level of dyskinesia is reduced. This results in an increased motor repertoire because of the increased SNR. Dyskinesia management is effective and should be pursued.

Situation 2: the clinician reduces medication dosage and the level of dyskinesia is reduced, but leads to a reduction in motor repertoire. As such, the dyskinesia portion of the noise is reduced but is accompanied by an increase in noise associated with typical parkinsonian symptoms present when medication is lacking, such as bradykinesia or rigidity. Here, the treatment regimen should be modified until situation 1 is achieved. If situation 1 cannot be achieved, it may be that having some dyskinesia is the preferred solution since the motor repertoire is greater with dyskinesia, as discussed by our group [293,296] and others [302]. Surgery may be considered as an alternative in this case because, as mentioned above, it may control dyskinesia possibly through a reduction in medication. The aforementioned approach would seem logical to movement disorders specialists, but may be more difficult to implement by less experienced clinicians treating patients with PD experiencing motor fluctuations.

Accordingly, we propose that there is a SNR related to dyskinesia below which the execution of a voluntary movement is rendered impossible (or not functionally possible). Whether this SNR is systematic across patients or specific to each patient is currently under investigation in our laboratory. We also propose that a reduction of dyskinesia amplitude through a proper medication regimen modification will result in an increased motor repertoire only if typical parkinsonian symptoms do not re-emerge to levels affecting significantly the SNR for specific tasks.

How may this strategy be translated into clinical practice? We propose that clinicians may be able to view treatment success as an optimization of each patient's motor repertoire, rather than simply targeting symptomatology. 


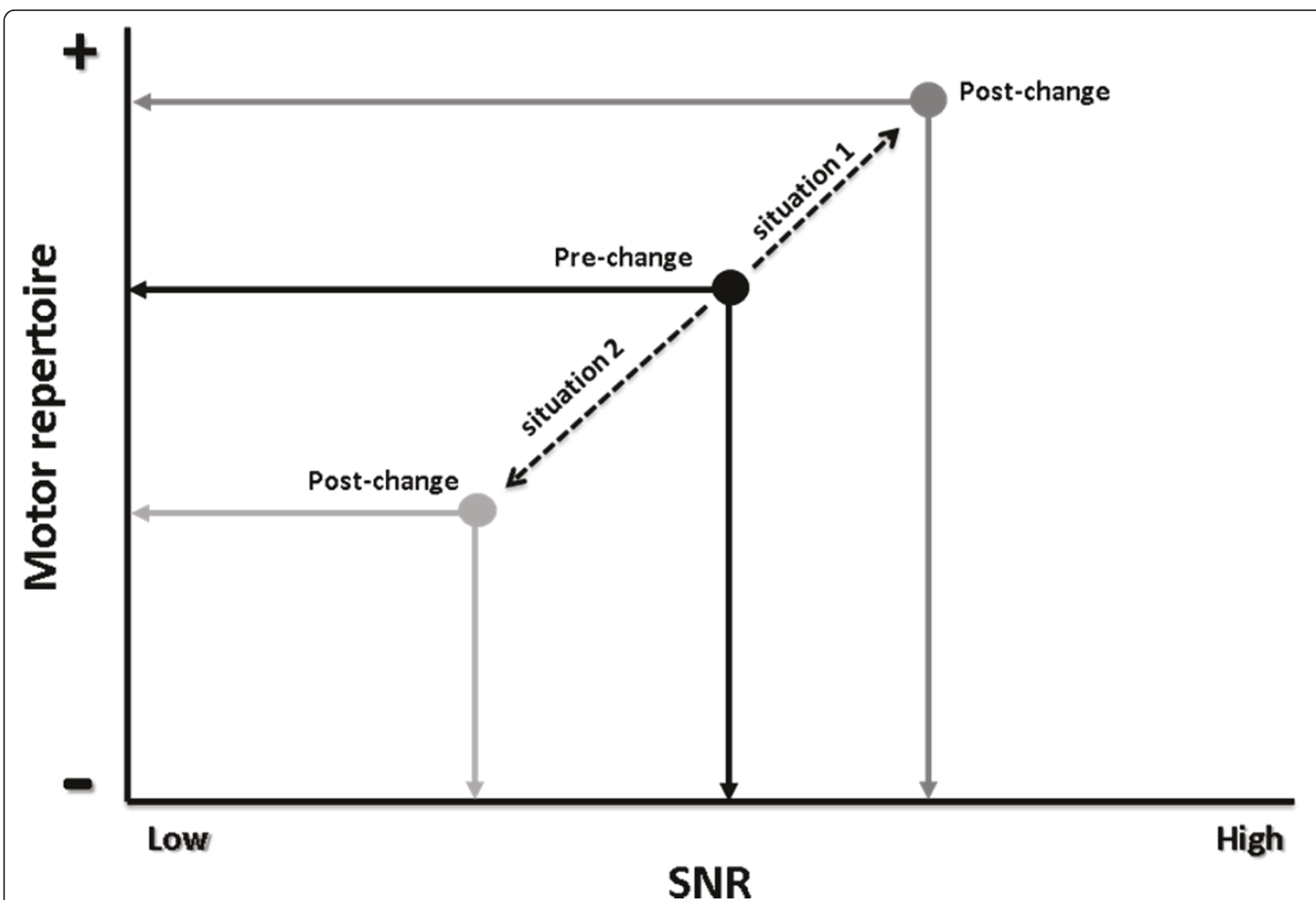

Figure 2 Two examples to illustrate opposite results following drug regimen change. In situation 1, a change in drug regimen decreased dyskinesia amplitude which then led to increased signal-to-noise ratio (SNR) (dark grey lines), and consequently increased motor repertoire. In situation 2, the same change in drug regimen also led to a reduction of dyskinesia amplitude. However, there is resurgence of typical motor symptoms associated with PD, thus increasing the noise, which will induce a decrease of overall SNR, hence a reduction in the motor repertoire (light grey lines). Here, the patient did not benefit from the reduction of dyskinesia, as his/her motor repertoire worsened. These examples illustrate the challenges faced by clinicians when managing dyskinesia. PD, Parkinson's disease.

Highly-trained movement disorders specialists probably use such an approach intuitively, but it is the lack of tools to help clinicians less experienced in dealing with PD patients that should be addressed. For instance, the presence of dyskinesia should be deemed detrimental if it significantly impacts the SNR and thus the motor repertoire of each patient. Based on the aforementioned evidence, there is a need to develop clinical evaluation protocols that specifically assess the motor repertoire of patients. Such a tool must reflect the wide range of movements performed during everyday life activities, it must incorporate a customizable section and be easy to perform, as well as give clinicians the ability to follow the progression within patients and compare the results between patients. While acknowledging that current clinical scales for the evaluation of dyskinesia provide invaluable information regarding their amplitude and impact on some activities of daily living, they lack the specificity for evaluating the range of the motor repertoire accessible to patients. We understand the immense difficulties associated with the development of a clinical scale of this type but, using such an evaluation, the clinician would be in a better position to determine whether the intervention was helpful to the patient, regardless of its effect on symptomatology. We are currently in the process of assessing the motor repertoire of patients without dyskinesia and with different levels of dyskinesia in order to develop a model of interaction between symptomatology and motor behaviors. Once this relationship is known, the development of such a tool could be envisioned.

\section{Summary}

The treatment of PD requires the evaluation of several motor symptoms affecting the quality of life of patients. The limited number of movement disorders specialists and the increasing number of patients with PD places a toll on health-care systems world-wide. The need to develop and implement evidence-based medicine is 
urgent. In this review, we proposed a novel way to view the clinical management of motor symptoms in PD and more specifically of dyskinesia. While we acknowledge that this view requires further testing, we believe that systematizing the approach to the treatment of motor symptoms in PD will lead to an improvement in patient quality of life and, hopefully, a relief on our health-care system.

\begin{abstract}
Abbreviations
AIMS: Abnormal Involuntary Movement Scale; AMPA: a-amino-3-hydroxy-5methyl-4-isoxazolepropionic acid; CDD: continuous drug delivery; CM/pF: centro-median-parafascicular complex; COMT: catechol-O-methyl tttransferase; DBS: deep brain stimulation; GPi: globus pallidus internus; LDOPA: L-3,4-dihydroxyphenylalanine; MAO-B: monoamine oxydase B; mGluR4: metabotropic glutamate receptor 4; mGluR5: metabotropic glutamate receptor 5; NMDA: N-methyl-D-aspartate; PD: Parkinson's disease; PPN: pedonculopontine nucleus; SNR: signal-to-noise ratio; STN: subthalamic nucleus; VL thalamus: ventrolateral thalamus.
\end{abstract}

\section{Competing interests}

JFD, BC, AFS and CD declare that they have no competing interests. MP has received research grants from Teva Neuroscience, Novartis, and Allergan. He has been a lecturer for Allergan, Merz, Novartis and Teva. He has participated in advisory boards for Merck, EMD Serono, Allergan, Merz, Novartis, and Teva.

\section{Authors' contributions}

JFD, BC and CD contributed to the design and content of the manuscript. AFS and MP contributed to the content of the manuscript. All authors contributed to revisions and approved the final version of the manuscript.

\section{Acknowledgements}

JFD and BC are each recipients of a Fonds de la Recherche du QuébecSanté Doctoral Scholarship. CD is supported by a Fonds de la Recherche du Québec-Santé salary grant. CD is also a principal investigator on a Natural Science and Engineering Research Council of Canada operating grant, Canadian Institute of Health Research emerging team grant and Canada Foundation for Innovation grant. This work was also supported in part by a Parkinson Society Canada grant to CD. AFS is a principal investigator on a Natural Science and Engineering Research Council of Canada operating grant. None of the funding bodies had a direct influence on manuscript preparation and submission.

\section{Authors' details}

'Department of Neurology and Neurosurgery, Montreal Neurological Institute, McGill University, 3801 University street, Montreal, Quebec, H3A 2B4, Canada. ${ }^{2}$ Centre de Recherche de I'Institut Universitaire de Gériatrie de Montréal, 4545 Chemin Queen-Mary, Montréal, Québec, H3W 1W4, Canada. ${ }^{3}$ Département des Sciences Biologiques, Université du Québec à Montréal, 141 Avenue Président-Kennedy, Montréal, Québec, H2X 1Y4, Canada. ${ }^{4} U n i t e ́$ des troubles du mouvement André-Barbeau, Centre Hospitalier de I'Université de Montréal, 1560 rue Sherbrooke Est, Montréal, Québec, H2L 4M1, Canada. ${ }^{5}$ Département de Kinanthropologie, Université du Québec à Montréal, 141 Avenue Président-Kennedy, Montréal, Québec, H2X 1Y4, Canada.

Received: 5 July 2012 Accepted: 20 March 2013

Published: 20 March 2013

\section{References}

1. Ehringer $\mathrm{H}$, Hornykiewicz O: [Distribution of noradrenaline and dopamine (3-hydroxytyramine) in the human brain and their behavior in diseases of the extrapyramidal system]. Klin Wochenschr 1960, 38:1236-1239.

2. Jankovic J: Parkinson's disease: clinical features and diagnosis. J Neurol Neurosurg Psychiatry 2008, 79(4):368-376.
3. Zgaljardic DJ, Foldi NS, Borod JC: Cognitive and behavioral dysfunction in Parkinson's disease: neurochemical and clinicopathological contributions. J Neural Transm 2004, 111:1287-1301.

4. Gallagher DA, Schrag A: Psychosis, apathy, depression and anxiety in Parkinson's disease. Neurobiol Dis 2012, 46:581-589.

5. Gagnon JF, Postuma RB, Mazza S, Doyon J, Montplaisir J: Rapid-eyemovement sleep behaviour disorder and neurodegenerative diseases. Lancet Neurol 2006, 5:424-432.

6. Postuma RB, Gagnon JF, Vendette M, Charland K, Montplaisir J: Manifestations of Parkinson disease differ in association with REM sleep behavior disorder. Mov Disord 2008, 23:1665-1672.

7. Tan LC: Mood disorders in Parkinson's disease. Parkinsonism Relat Disord 2012, 18(Suppl 1):S74-76.

8. Hemmerle AM, Herman JP, Seroogy KB: Stress, depression and Parkinson's disease. Exp Neurol 2012, 233:79-86.

9. Peavy GM: Mild cognitive deficits in Parkinson disease: where there is bradykinesia, there is bradyphrenia. Neurology 2010, 75:1038-1039.

10. Perez Trullen JM, Modrego Pardo PJ, Vazquez Andre ML: Bradyphrenia and parkinsonism. Age Ageing 1994, 23:524.

11. Rogers D: Bradyphrenia in parkinsonism: a historical review. Psychol Med 1986, 16:257-265.

12. Rogers D: Bradyphrenia in Parkinson's disease. Br J Hosp Med 1988, 39:128-130.

13. Doty RL: Olfaction in Parkinson's disease and related disorders. Neurobiol Dis 2012, 46:527-552.

14. Del Sorbo F, Albanese A: Clinical management of pain and fatigue in Parkinson's disease. Parkinsonism Relat Disord 2012, 18(Suppl 1):S233-236.

15. de Rijk MC, Breteler MM, Graveland GA, Ott A, Grobbee DE, van der Meche FG, Hofman A: Prevalence of Parkinson's disease in the elderly: the Rotterdam Study. Neurology 1995, 45:2143-2146.

16. de Rijk MC, Launer LJ, Berger K, Breteler MM, Dartigues JF, Baldereschi M, Fratiglioni L, Lobo A, Martinez-Lage J, Trenkwalder C, Hofman A: Prevalence of Parkinson's disease in Europe: a collaborative study of populationbased cohorts. Neurologic Diseases in the Elderly Research Group. Neurology 2000, 54(Suppl 5):S21-23.

17. de Rijk MC, Tzourio C, Breteler MM, Dartigues JF, Amaducci L, Lopez-Pousa S, Manubens-Bertran JM, Alperovitch A, Rocca WA: Prevalence of parkinsonism and Parkinson's disease in Europe: the EUROPARKINSON Collaborative Study. European Community Concerted Action on the Epidemiology of Parkinson's disease. J Neurol Neurosurg Psychiatry 1997, 62:10-15.

18. Li SC, Schoenberg BS, Wang CC, Cheng XM, Rui DY, Bolis CL, Schoenberg DG: A prevalence survey of Parkinson's disease and other movement disorders in the People's Republic of China. Arch Neurol 1985, 42:655-657.

19. Schrag A, Ben-Shlomo Y, Quinn NP: Cross sectional prevalence survey of idiopathic Parkinson's disease and Parkinsonism in London. BMJ 2000, 321:21-22.

20. de Lau LM, Giesbergen PC, de Rijk MC, Hofman A, Koudstaal PJ, Breteler MM: Incidence of parkinsonism and Parkinson disease in a general population: the Rotterdam Study. Neurology 2004, 63:1240-1244.

21. Van Den Eeden SK, Tanner CM, Bernstein AL, Fross RD, Leimpeter A, Bloch DA, Nelson LM: Incidence of Parkinson's disease: variation by age, gender, and race/ethnicity. Am J Epidemiol 2003, 157:1015-1022.

22. Quinn N, Critchley P, Marsden CD: Young onset Parkinson's disease. Mov Disord 1987, 2:73-91.

23. Morris ME: Movement disorders in people with Parkinson disease: a model for physical therapy. Phys Ther 2000, 80:578-597.

24. Hughes AJ, Daniel SE, Kilford L, Lees AJ: Accuracy of clinical diagnosis of idiopathic Parkinson's disease: a clinico-pathological study of 100 cases. I Neurol Neurosurg Psychiatry 1992, 55:181-184.

25. Diamond SG, Markham CH, Hoehn MM, McDowell FH, Muenter MD: Effect of age at onset on progression and mortality in Parkinson's disease. Neurology 1989, 39:1187-1190.

26. Harada H, Nishikawa S, Takahashi K: Epidemiology of Parkinson's disease in a Japanese city. Arch Neurol 1983, 40:151-154.

27. Barbeau A, Pourcher E: New data on the genetics of Parkinson's disease. Can J Neurol Sci 1982, 9:53-60.

28. Schrag A, Ben-Shlomo Y, Brown R, Marsden CD, Quinn N: Young-onset Parkinson's disease revisited-clinical features, natural history, and mortality. Mov Disord 1998, 13:885-894. 
29. Parkinson Study Group: A controlled trial of rasagiline in early Parkinson disease: the TEMPO Study. Arch Neurol 2002, 59:1937-1943.

30. Kurlan R, Rubin AJ, Miller C, Rivera-Calimlim L, Clarke A, Shoulson I: Duodenal delivery of levodopa for on-off fluctuations in parkinsonism: preliminary observations. Ann Neurol 1986, 20:262-265.

31. Gibb WR, Lees AJ: A comparison of clinical and pathological features of young- and old-onset Parkinson's disease. Neurology 1988, 38:1402-1406.

32. Pederzoli M, Girotti F, Scigliano G, Aiello G, Carella F, Caraceni T: L-DOPA long-term treatment in Parkinson's disease: age-related side effects. Neurology 1983, 33:1518-1522.

33. Ishihara LS, Cheesbrough A, Brayne C, Schrag A: Estimated life expectancy of Parkinson's patients compared with the UK population. J Neurol Neurosurg Psychiatry 2007, 78:1304-1309.

34. Schrag A, Hovris A, Morley D, Quinn N, Jahanshahi M: Young- versus olderonset Parkinson's disease: impact of disease and psychosocial consequences. Mov Disord 2003, 18:1250-1256.

35. Kostic V, Przedborski S, Flaster E, Sternic N: Early development of levodopa-induced dyskinesias and response fluctuations in young-onset Parkinson's disease. Neurology 1991, 41:202-205.

36. Albin RL, Young AB, Penney JB: The functional anatomy of basal ganglia disorders. Trends Neurosci 1989, 12:366-375.

37. Alexander GE, DeLong MR, Strick PL: Parallel organization of functionally segregated circuits linking basal ganglia and cortex. Annu Rev Neurosci 1986, 9:357-381.

38. Crossman AR: Primate models of dyskinesia: the experimental approach to the study of basal ganglia-related involuntary movement disorders. Neuroscience 1987, 21:1-40.

39. Alexander GE, Crutcher MD: Functional architecture of basal ganglia circuits: neural substrates of parallel processing. Trends Neurosci 1990, 13:266-271.

40. Kravitz AV, Freeze BS, Parker PR, Kay K, Thwin MT, Deisseroth K, Kreitzer AC: Regulation of parkinsonian motor behaviours by optogenetic control of basal ganglia circuitry. Nature 2010, 466:622-626.

41. Fox SH, Katzenschlager R, Lim SY, Ravina B, Seppi K, Coelho M, Poewe W, Rascol O, Goetz CG, Sampaio C: The Movement Disorder Society Evidence-Based Medicine Review Update: treatments for the motor symptoms of Parkinson's disease. Mov Disord 2011, 26(Suppl 3):S2-41.

42. Cenci MA, Ohlin KE, Odin P: Current options and future possibilities for the treatment of dyskinesia and motor fluctuations in Parkinson's disease. CNS Neurol Disord Drug Targets 2011, 10:670-684.

43. Birkmayer W, Hornykiewicz O: [The L-3,4-dioxyphenylalanine (DOPA)effect in Parkinson-akinesia]. Wien Klin Wochenschr 1961, 73:787-788.

44. Fahn S: The history of dopamine and levodopa in the treatment of Parkinson's disease. Mov Disord 2008, 23(Suppl 3):S497-508.

45. Barbeau A, Murphy GF, Sourkes TL: Excretion of dopamine in diseases of basal ganglia. Science 1961, 133:1706-1707.

46. Stern MB, Marek KL, Friedman J, Hauser RA, LeWitt PA, Tarsy D, Olanow CW Double-blind, randomized, controlled trial of rasagiline as monotherapy in early Parkinson's disease patients. Mov Disord 2004, 19:916-923.

47. Nutt JG, Fellman JH: Pharmacokinetics of levodopa. Clin Neuropharmacol 1984, 7:35-49.

48. Bianchine JR, Messiha FS, Hsu TH: Peripheral aromatic L-amino acids decarboxylase inhibitor in parkinsonism. II. Effect on metabolism of L-214 C-dopa. Clin Pharmacol Ther 1972, 13:584-594.

49. Kuruma I, Bartholini G, Tissot R, Fletscher A: Comparative investigation of inhibitors of extracerebral dopa decarboxylase in man and rats. J Pharm Pharmacol 1972, 24:289-294.

50. Contin M, Riva R, Albani F, Baruzzi A: Pharmacokinetic optimisation in the treatment of Parkinson's disease. Clin Pharmacokinet 1996, 30:463-481.

51. Nyholm D: Pharmacokinetic optimisation in the treatment of Parkinson's disease: an update. Clin Pharmacokinet 2006, 45:109-136.

52. Riederer $\mathrm{P}$, Youdim MB: Monoamine oxidase activity and monoamine metabolism in brains of parkinsonian patients treated with I-deprenyl. J Neurochem 1986, 46:1359-1365.

53. Effect of deprenyl on the progression of disability in early Parkinson's disease. The Parkinson Study Group. N Engl J Med 1989, 321:1364-1371.

54. Palhagen S, Heinonen EH, Hagglund J, Kaugesaar T, Kontants H, MakiIkola O, Palm R, Turunen J: Selegiline delays the onset of disability in de novo parkinsonian patients. Swedish Parkinson Study Group. Neurology 1998, 51:520-525.

55. Seppi K, Weintraub D, Coelho M, Perez-Lloret S, Fox SH, Katzenschlager R, Hametner EM, Poewe W, Rascol O, Goetz CG, Sampaio C: The Movement
Disorder Society Evidence-Based Medicine Review Update: treatments for the non-motor symptoms of Parkinson's disease. Mov Disord 2011, 26(Suppl 3):S42-80.

56. Watts RL: The role of dopamine agonists in early Parkinson's disease. Neurology 1997, 49(Suppl 1):S34-48.

57. Olanow CW: The role of dopamine agonists in the treatment of early Parkinson's disease. Neurology 2002, 58(Suppl 1):S33-41.

58. Scott RM, Brody JA, Cooper IS: The effect of thalamotomy on the progress of unilateral Parkinson's disease. J Neurosurg 1970, 32:286-288.

59. Duval C, Panisset M, Bertrand G, Sadikot AF: Evidence that ventrolateral thalamotomy may eliminate the supraspinal component of both pathological and physiological tremors. Exp Brain Res 2000, 132:216-222.

60. Duval C, Panisset M, Strafella AP, Sadikot AF: The impact of ventrolateral thalamotomy on tremor and voluntary motor behavior in patients with Parkinson's disease. Exp Brain Res 2006, 170:160-171.

61. Duval C, Strafella AP, Sadikot AF: The impact of ventrolateral thalamotomy on high-frequency components of tremor. Clin Neurophysiol 2005, 116:1391-1399.

62. Atkinson JD, Collins DL, Bertrand G, Peters TM, Pike GB, Sadikot AF: Optimal location of thalamotomy lesions for tremor associated with Parkinson disease: a probabilistic analysis based on postoperative magnetic resonance imaging and an integrated digital atlas. J Neurosurg 2002, 96:854-866.

63. Ohye C, Higuchi Y, Shibazaki T, Hashimoto T, Koyama T, Hirai T, Matsuda S, Serizawa T, Hori T, Hayashi M, Ochiai T, Samura H, Yamashiro K: Gamma knife thalamotomy for Parkinson disease and essential tremor: a prospective multicenter study. Neurosurgery 2012, 70:526-535, discussion 535-526.

64. Fox MW, Ahlskog JE, Kelly PJ: Stereotactic ventrolateralis thalamotomy for medically refractory tremor in post-levodopa era Parkinson's disease patients. J Neurosurg 1991, 75:723-730.

65. Hurtig HI, Stern MB: Thalamotomy for Parkinson's disease. J Neurosurg 1985, 62:163-165.

66. Matsumoto K, Shichijo F, Fukami T: Long-term follow-up review of cases of Parkinson's disease after unilateral or bilateral thalamotomy. $J$ Neurosurg 1984, 60:1033-1044.

67. Mosso JA, Rand RW: Management of parkinson's disease-combined therapy with levodopa and thalamotomy. West J Med 1975, 122:1-6.

68. Tasker RR, Munz M, Junn FS, Kiss ZH, Davis K, Dostrovsky JO, Lozano AM: Deep brain stimulation and thalamotomy for tremor compared. Acta Neurochir Suppl 1997, 68:49-53.

69. Tasker RR, Siqueira J, Hawrylyshyn P, Organ LW: What happened to VIM thalamotomy for Parkinson's disease? App/ Neurophysiol 1983, 46:68-83.

70. de Bie RM, de Haan RJ, Schuurman PR, Esselink RA, Bosch DA, Speelman JD: Morbidity and mortality following pallidotomy in Parkinson's disease: a systematic review. Neurology 2002, 58:1008-1012.

71. De Bie RM, Schuurman PR, Esselink RA, Bosch DA, Speelman JD: Bilateral pallidotomy in Parkinson's disease: a retrospective study. Mov Disord 2002, 17:533-538.

72. Esselink RA, de Bie RM, de Haan RJ, Lenders MW, Nijssen PC, Staal MJ, Smeding HM, Schuurman PR, Bosch DA, Speelman JD: Unilateral pallidotomy versus bilateral subthalamic nucleus stimulation in PD: a randomized trial. Neurology 2004, 62:201-207.

73. Esselink RA, de Bie RM, de Haan RJ, Lenders MW, Nijssen PC, van Laar T, Schuurman PR, Bosch DA, Speelman JD: Long-term superiority of subthalamic nucleus stimulation over pallidotomy in Parkinson disease. Neurology 2009, 73:151-153.

74. Esselink RA, de Bie RM, de Haan RJ, Steur EN, Beute GN, Portman AT, Schuurman PR, Bosch DA, Speelman JD: Unilateral pallidotomy versus bilateral subthalamic nucleus stimulation in Parkinson's disease: one year follow-up of a randomised observer-blind multi centre trial. Acta Neurochir (Wien) 2006, 148:1247-1255, discussion 1255.

75. Smeding HM, Esselink RA, Schmand B, Koning-Haanstra M, Nijhuis I, Wijnalda EM, Speelman JD: Unilateral pallidotomy versus bilateral subthalamic nucleus stimulation in PD-a comparison of neuropsychological effects. J Neurol 2005, 252:176-182.

76. Coban A, Hanagasi HA, Karamursel S, Barlas O: Comparison of unilateral pallidotomy and subthalamotomy findings in advanced idiopathic Parkinson's disease. Br J Neurosurg 2009, 23:23-29.

77. Bronstein JM, DeSalles A, DeLong MR: Stereotactic pallidotomy in the treatment of Parkinson disease: an expert opinion. Arch Neurol 1999, 56:1064-1069. 
78. Gironell A, Kulisevsky J, Rami L, Fortuny N, Garcia-Sanchez C, PascualSedano B: Effects of pallidotomy and bilateral subthalamic stimulation on cognitive function in Parkinson disease. A controlled comparative study. J Neurol 2003, 250:917-923.

79. Hariz Ml, Bergenheim AT: A 10-year follow-up review of patients who underwent Leksell's posteroventral pallidotomy for Parkinson disease. J Neurosurg 2001, 94:552-558.

80. Intemann PM, Masterman D, Subramanian I, DeSalles A, Behnke E, Frysinger R, Bronstein JM: Staged bilateral pallidotomy for treatment of Parkinson disease. J Neurosurg 2001, 94:437-444.

81. Alvarez L, Macias R, Pavon N, Lopez G, Rodriguez-Oroz MC, Rodriguez R, Alvarez M, Pedroso I, Teijeiro J, Fernandez R, Casabona E, Salazar S, Maragoto C, Carballo M, García I, Guridi J, Juncos JL, DeLong MR, Obeso JA: Therapeutic efficacy of unilateral subthalamotomy in Parkinson's disease: results in 89 patients followed for up to 36 months. J Neurol Neurosurg Psychiatry 2009, 80:979-985.

82. Merello M, Tenca E, Perez Lloret S, Martin ME, Bruno V, Cavanagh S, Antico J, Cerquetti D, Leiguarda R: Prospective randomized 1-year followup comparison of bilateral subthalamotomy versus bilateral subthalamic stimulation and the combination of both in Parkinson's disease patients: a pilot study. $\mathrm{Br} J$ Neurosurg 2008, 22:415-422.

83. Alvarez L, Macias R, Lopez G, Alvarez E, Pavon N, Rodriguez-Oroz MC, Juncos JL, Maragoto C, Guridi J, Litvan I, Tolosa ES, Koller W, Vitek J, DeLong MR, Obeso JA: Bilateral subthalamotomy in Parkinson's disease: initial and long-term response. Brain 2005, 128:570-583.

84. Gill SS, Heywood P: Bilateral dorsolateral subthalamotomy for advanced Parkinson's disease. Lancet 1997, 350:1224.

85. Obeso JA, Jahanshahi M, Alvarez L, Macias R, Pedroso I, Wilkinson L, Pavon N, Day B, Pinto S, Rodriguez-Oroz MC, Tejeiro J, Artieda J, Talelli P, Swayne O, Rodríguez R, Bhatia K, Rodriguez-Diaz M, Lopez G, Guridi J, Rothwell JC: What can man do without basal ganglia motor output? The effect of combined unilateral subthalamotomy and pallidotomy in a patient with Parkinson's disease. Exp Neurol 2009, 220:283-292.

86. Patel NK, Heywood P, O'Sullivan K, McCarter R, Love S, Gill SS: Unilateral subthalamotomy in the treatment of Parkinson's disease. Brain 2003, 126:1136-1145.

87. Su PC, Tseng HM: Subthalamotomy for end-stage severe Parkinson's disease. Mov Disord 2002, 17:625-627, author reply 627.

88. Su PC, Tseng HM, Liu HM, Yen RF, Liou HH: Subthalamotomy for advanced Parkinson disease. J Neurosurg 2002, 97:598-606.

89. Su PC, Tseng HM, Liu HM, Yen RF, Liou HH: Treatment of advanced Parkinson's disease by subthalamotomy: one-year results. Mov Disord 2003, 18:531-538.

90. Tseng HM, Su PC, Liu HM, Liou HH, Yen RF: Bilateral subthalamotomy for advanced Parkinson disease. Surg Neurol 2007, 68(Suppl 1):S43-50, discussion S50-41.

91. Ponce FA, Lozano AM: Deep brain stimulation state of the art and novel stimulation targets. Prog Brain Res 2010, 184:311-324.

92. Videnovic A, Metman LV: Deep brain stimulation for Parkinson's disease: prevalence of adverse events and need for standardized reporting. Mov Disord 2008, 23:343-349.

93. Seijo FJ, Alvarez-Vega MA, Gutierrez JC, Fdez-Glez F, Lozano B: Complications in subthalamic nucleus stimulation surgery for treatment of Parkinson's disease. Review of 272 procedures. Acta Neurochir (Wien) 2007, 149:867-875, discussion 876.

94. Hu X, Jiang X, Zhou X, Liang J, Wang L, Cao Y, Liu J, Jin A, Yang P: Avoidance and management of surgical and hardware-related complications of deep brain stimulation. Stereotact Funct Neurosurg 2010, 88:296-303.

95. Bronstein JM, Tagliati M, Alterman RL, Lozano AM, Volkmann J, Stefani A, Horak FB, Okun MS, Foote KD, Krack P, Pahwa R, Henderson JM, Hariz MI, Bakay RA, Rezai A, Marks WJ Jr, Moro E, Vitek JL, Weaver FM, Gross RE, DeLong MR: Deep brain stimulation for Parkinson disease: an expert consensus and review of key issues. Arch Neurol 2011, 68:165.

96. Lanotte M, Verna G, Panciani PP, Taveggia A, Zibetti M, Lopiano L, Ducati A: Management of skin erosion following deep brain stimulation. Neurosurg Rev 2009, 32:111-114, discussion 114-115.

97. Lyons KE, Wilkinson SB, Overman J, Pahwa R: Surgical and hardware complications of subthalamic stimulation: a series of 160 procedures. Neurology 2004, 63:612-616.
98. Hariz MI, Rehncrona S, Quinn NP, Speelman JD, Wensing C: Multicenter study on deep brain stimulation in Parkinson's disease: an independent assessment of reported adverse events at 4 years. Mov Disord 2008, 23:416-421.

99. Follett KA, Torres-Russotto D: Deep brain stimulation of globus pallidus interna, subthalamic nucleus, and pedunculopontine nucleus for Parkinson's disease: which target? Parkinsonism Relat Disord 2012, 18(Suppl 1):S165-167.

100. Weaver FM, Follett KA, Stern M, Luo P, Harris CL, Hur K, Marks WJ Jr, Rothlind J, Sagher O, Moy C, Pahwa R, Burchiel K, Hogarth P, Lai EC, Duda JE, Holloway K, Samii A, Horn S, Bronstein JM, Stoner G, Starr PA, Simpson R, Baltuch G, De Salles A, Huang GD, Reda DJ, CSP 468 Study Group: Randomized trial of deep brain stimulation for Parkinson disease: thirty-six-month outcomes. Neurology 2012, 79:55-65.

101. Gervais-Bernard H, Xie-Brustolin J, Mertens P, Polo G, Klinger H, Adamec D, Broussolle $E$, Thobois $S$ : Bilateral subthalamic nucleus stimulation in advanced Parkinson's disease: five year follow-up. J Neurol 2009, 256:225-233.

102. Kleiner-Fisman G, Herzog J, Fisman DN, Tamma F, Lyons KE, Pahwa R, Lang $A E$, Deuschl G: Subthalamic nucleus deep brain stimulation: summary and meta-analysis of outcomes. Mov Disord 2006, 21(Suppl 14): S290-304.

103. Follett KA, Weaver FM, Stern M, Hur K, Harris CL, Luo P, Marks WJ Jr, Rothlind J, Sagher O, Moy C, Pahwa R, Burchiel K, Hogarth P, Lai EC, Duda JE, Holloway K, Samii A, Horn S, Bronstein JM, Stoner G, Starr PA, Simpson R, Baltuch G, De Salles A, Huang GD, Reda DJ, CSP 468 Study Group: Pallidal versus subthalamic deep-brain stimulation for Parkinson's disease. N Engl J Med 2010, 362:2077-2091.

104. Odekerken VJ, van Laar T, Staal MJ, Mosch A, Hoffmann CF, Nijssen PC, Beute GN, van Vugt JP, Lenders MW, Contarino MF, Mink MS, Bour LJ, van den Munckhof P, Schmand BA, de Haan RJ, Schuurman PR, de Bie RM: Subthalamic nucleus versus globus pallidus bilateral deep brain stimulation for advanced Parkinson's disease (NSTAPS study): a randomised controlled trial. Lancet Neurol 2013, 12:37-55.

105. Okun MS, Foote KD: Parkinson's disease DBS: what, when, who and why? The time has come to tailor DBS targets. Expert Rev Neurother 2010, 10:1847-1857.

106. Taba HA, Wu SS, Foote KD, Hass CJ, Fernandez HH, Malaty IA, Rodriguez RL, Dai $Y$, Zeilman PR, Jacobson CE, Okun MS: A closer look at unilateral versus bilateral deep brain stimulation: results of the National Institutes of Health COMPARE cohort. J Neurosurg 2010, 113:1224-1229.

107. Moro E, Lozano AM, Pollak P, Agid Y, Rehncrona S, Volkmann J, Kulisevsky J, Obeso JA, Albanese A, Hariz MI, Quinn NP, Speelman JD, Benabid AL, Fraix V, Mendes A, Welter ML, Houeto $J$, Cornu P, Dormont D, Tornqvist AL, Ekberg R, Schnitzler A, Timmermann L, Wojtecki L, Gironell A, Rodriguez-Oroz MC, Guridi J, Bentivoglio AR, Contarino MF, Romito L, et al: Long-term results of a multicenter study on subthalamic and pallidal stimulation in Parkinson's disease. Mov Disord 2010, 25:578-586.

108. Volkmann J, Albanese A, Kulisevsky J, Tornqvist AL, Houeto JL, Pidoux B, Bonnet AM, Mendes A, Benabid AL, Fraix V, Van Blercom N, Xie J, Obeso J, Rodriguez-Oroz MC, Guridi J, Schnitzler A, Timmermann L, Gironell AA, Molet J, Pascual-Sedano B, Rehncrona S, Moro E, Lang AC, Lozano AM, Bentivoglio AR, Scerrati M, Contarino MF, Romito L, Janssens M, Agid Y: Long-term effects of pallidal or subthalamic deep brain stimulation on quality of life in Parkinson's disease. Mov Disord 2009, 24:1154-1161.

109. Anderson VC, Burchiel KJ, Hogarth P, Favre J, Hammerstad JP: Pallidal vs subthalamic nucleus deep brain stimulation in Parkinson disease. Arch Neurol 2005, 62:554-560.

110. Apetauerova D, Ryan RK, Ro SI, Arle J, Shils J, Papavassiliou E, Tarsy D: End of day dyskinesia in advanced Parkinson's disease can be eliminated by bilateral subthalamic nucleus or globus pallidus deep brain stimulation. Mov Disord 2006, 21:1277-1279.

111. Romito LM, Contarino MF, Vanacore N, Bentivoglio AR, Scerrati M, Albanese A: Replacement of dopaminergic medication with subthalamic nucleus stimulation in Parkinson's disease: long-term observation. Mov Disord 2009, 24:557-563.

112. Benabid AL, Torres N: New targets for DBS. Parkinsonism Relat Disord 2012, 18(Suppl 1):S21-23.

113. Lee MS, Rinne JO, Marsden CD: The pedunculopontine nucleus: its role in the genesis of movement disorders. Yonsei Med J 2000, 41:167-184. 
114. Moreau C, Defebvre L, Devos D, Marchetti F, Destee A, Stefani A, Peppe A: STN versus PPN-DBS for alleviating freezing of gait: toward a frequency modulation approach? Mov Disord 2009, 24:2164-2166.

115. Stefani A, Lozano AM, Peppe A, Stanzione P, Galati S, Tropepi D, Pierantozzi M, Brusa L, Scarnati E, Mazzone P: Bilateral deep brain stimulation of the pedunculopontine and subthalamic nuclei in severe Parkinson's disease. Brain 2007, 130:1596-1607.

116. Yelnik J: PPN or PPD, what is the target for deep brain stimulation in Parkinson's disease? Brain 2007, 130:e79, author reply e80.

117. Peppe A, Gasbarra A, Stefani A, Chiavalon C, Pierantozzi M, Fermi E, Stanzione P, Caltagirone C, Mazzone P: Deep brain stimulation of CM/PF of thalamus could be the new elective target for tremor in advanced Parkinson's Disease? Parkinsonism Relat Disord 2008, 14:501-504.

118. Karlsson F, Unger E, Wahlgren S, Blomstedt P, Linder J, Nordh E, Zafar H, van Doorn J: Deep brain stimulation of caudal zona incerta and subthalamic nucleus in patients with Parkinson's disease: effects on diadochokinetic rate. Parkinsons Dis 2011, 2011:605607, doi: 10.4061/2011/605607.

119. Lundgren S, Saeys T, Karlsson F, Olofsson K, Blomstedt P, Linder J, Nordh E, Zafar $H$, van Doorn J: Deep brain stimulation of caudal zona incerta and subthalamic nucleus in patients with Parkinson's disease: effects on voice intensity. Parkinsons Dis 2011, 2011:658956, doi: 10.4061/2011/ 658956.

120. Sundstedt S, Olofsson K, van Doorn J, Linder J, Nordh E, Blomstedt P: Swallowing function in Parkinson's patients following Zona Incerta deep brain stimulation. Acta Neurol Scand 2012, 126:350356.

121. Taira T: Will ventralis intermedius deep brain stimulation for tremor be replaced by posterior subthalamic area or caudal zona incerta stimulation? World Neurosurg 2012, 78:445-446.

122. Hauser RA, Schwarzschild MA: Adenosine A2A receptor antagonists for Parkinson's disease: rationale, therapeutic potential and clinical experience. Drugs Aging 2005, 22:471-482.

123. Hsieh PW, Hung CF, Fang JY: Current prodrug design for drug discovery. Curr Pharm Des 2009, 15:2236-2250.

124. Sozio P, Cerasa LS, Abbadessa A, Di Stefano A: Designing prodrugs for the treatment of Parkinson's disease. Expert Opin Drug Discov 2012, 7:385-406.

125. Politis M, Wu K, Loane C, Kiferle L, Molloy S, Brooks DJ, Piccini P: Staging of serotonergic dysfunction in Parkinson's disease: an in vivo 11C-DASB PET study. Neurobiol Dis 2010, 40:216-221.

126. Politis M, Wu K, Loane C, Quinn NP, Brooks DJ, Rehncrona S, Bjorklund A, Lindvall O, Piccini P: Serotonergic neurons mediate dyskinesia side effects in Parkinson's patients with neural transplants. Sci Trans/ Med 2010, 2:38ra46.

127. Dunnett SB, Bjorklund A, Lindvall O: Cell therapy in Parkinson's disease stop or go? Nat Rev Neurosci 2001, 2:365-369.

128. Marks WJ Jr, Bartus RT, Siffert J, Davis CS, Lozano A, Boulis N, Vitek J, Stacy M, Turner D, Verhagen L, Bakay R, Watts R, Guthrie B, Jankovic J, Simpson R, Tagliati M, Alterman R, Stern M, Baltuch G, Starr PA, Larson PS, Ostrem JL, Nutt J, Kieburtz K, Kordower JH, Olanow CW: Gene delivery of AAV2-neurturin for Parkinson's disease: a double-blind, randomised, controlled trial. Lancet Neurol 2010, 9:1164-1172.

129. Marks WJ Jr, Ostrem JL, Verhagen L, Starr PA, Larson PS, Bakay RA, Taylor R, Cahn-Weiner DA, Stoessl AJ, Olanow CW, Bartus RT: Safety and tolerability of intraputaminal delivery of CERE-120 (adeno-associated virus serotype 2-neurturin) to patients with idiopathic Parkinson's disease: an openlabel, phase I trial. Lancet Neurol 2008, 7:400-408.

130. Gasmi M, Herzog CD, Brandon EP, Cunningham JJ, Ramirez GA, Ketchum ET, Bartus RT: Striatal delivery of neurturin by CERE-120, an AAV2 vector for the treatment of dopaminergic neuron degeneration in Parkinson's disease. Mol Ther 2007, 15:62-68.

131. Herzog CD, Dass B, Holden JE, Stansell J, Gasmi M, Tuszynski MH, Bartus RT, Kordower JH: Striatal delivery of CERE-120, an AAV2 vector encoding human neurturin, enhances activity of the dopaminergic nigrostriatal system in aged monkeys. Mov Disord 2007, 22:1124-1132.

132. Kaplitt MG, Feigin A, Tang C, Fitzsimons HL, Mattis P, Lawlor PA, Bland RJ, Young D, Strybing K, Eidelberg D, During MJ: Safety and tolerability of gene therapy with an adeno-associated virus (AAV) borne GAD gene for Parkinson's disease: an open label, phase I trial. Lancet 2007, 369:2097-2105.

133. LeWitt PA, Rezai AR, Leehey MA, Ojemann SG, Flaherty AW, Eskandar EN, Kostyk SK, Thomas K, Sarkar A, Siddiqui MS, Tatter SB, Schwalb JM, Poston KL, Henderson JM, Kurlan RM, Richard IH, Van Meter L, Sapan CV,
During MJ, Kaplitt MG, Feigin A: AAV2-GAD gene therapy for advanced Parkinson's disease: a double-blind, sham-surgery controlled, randomised trial. Lancet Neurol 2011, 10:309-319.

134. Luo J, Kaplitt MG, Fitzsimons HL, Zuzga DS, Liu Y, Oshinsky ML, During MJ: Subthalamic GAD gene therapy in a Parkinson's disease rat model. Science 2002, 298:425-429.

135. Sgambato-Faure V, Cenci MA: Glutamatergic mechanisms in the dyskinesias induced by pharmacological dopamine replacement and deep brain stimulation for the treatment of Parkinson's disease. Prog Neurobiol 2012, 96:69-86.

136. Krack P, Batir A, Van Blercom N, Chabardes S, Fraix V, Ardouin C, Koudsie A, Limousin PD, Benazzouz A, LeBas JF, Benabid AL, Pollak P: Five-year followup of bilateral stimulation of the subthalamic nucleus in advanced Parkinson's disease. N Engl J Med 2003, 349:1925-1934.

137. Krack P, Fraix V, Mendes A, Benabid AL, Pollak P: Postoperative management of subthalamic nucleus stimulation for Parkinson's disease. Mov Disord 2002, 17(Suppl 3):S188-197.

138. Limousin P, Pollak P, Hoffmann D, Benazzouz A, Perret JE, Benabid AL: Abnormal involuntary movements induced by subthalamic nucleus stimulation in parkinsonian patients. Mov Disord 1996, 11:231-235.

139. Hagell $P$, Piccini $P$, Bjorklund A, Brundin P, Rehncrona S, Widner $H, C$ rabb L, Pavese N, Oertel WH, Quinn N, Brooks DJ, Lindvall O: Dyskinesias following neural transplantation in Parkinson's disease. Nat Neurosci 2002, 5:627-628.

140. Freed CR, Greene PE, Breeze RE, Tsai WY, DuMouchel W, Kao R, Dillon S, Winfield H, Culver S, Trojanowski JQ, Eidelberg D, Fahn S: Transplantation of embryonic dopamine neurons for severe Parkinson's disease. N Engl J Med 2001, 344:710-719.

141. Politis M: Dyskinesias after neural transplantation in Parkinson's disease: what do we know and what is next? BMC Med 2010, 8:80.

142. Ahlskog JE, Muenter MD: Frequency of levodopa-related dyskinesias and motor fluctuations as estimated from the cumulative literature. Mov Disord 2001, 16:448-458.

143. Fahn S: The spectrum of levodopa-induced dyskinesias. Ann Neurol 2000, 47(Suppl 1):S2-9, discussion S9-11.

144. Klawans HL, Goetz C, Bergen D: Levodopa-induced myoclonus. Arch Neurol 1975, 32:330-334.

145. Nutt JG: Motor fluctuations and dyskinesia in Parkinson's disease. Parkinsonism Relat Disord 2001, 8:101-108.

146. Gour J, Edwards R, Lemieux S, Ghassemi M, Jog M, Duval C: Movement patterns of peak-dose levodopa-induced dyskinesias in patients with Parkinson's disease. Brain Res Bull 2007, 74:66-74.

147. Fenney A, Jog MS, Duval C: Short-term variability in amplitude and motor topography of whole-body involuntary movements in Parkinson's disease dyskinesias and in Huntington's chorea. Clin Neurol Neurosurg 2008, 110:160-167.

148. Chelaru MI, Duval C, Jog M: Levodopa-induced dyskinesias detection based on the complexity of involuntary movements. J Neurosci Methods 2010, 186:81-89.

149. Mann RK, Edwards R, Zhou J, Jog M, Duval C: Intra- and inter-limb coherency during stance in non-dyskinetic and dyskinetic patients with Parkinson's disease. Clin Neurol Neurosurg 2010, 112:392-399.

150. Mann RK, Edwards R, Zhou J, Fenney A, Jog M, Duval C: Comparing movement patterns associated with Huntington's chorea and Parkinson's dyskinesia. Exp Brain Res 2012, 218:639-654.

151. Hallett PJ, Dunah AW, Ravenscroft P, Zhou S, Bezard E, Crossman AR, Brotchie JM, Standaert DG: Alterations of striatal NMDA receptor subunits associated with the development of dyskinesia in the MPTP-lesioned primate model of Parkinson's disease. Neuropharmacology 2005, 48:503-516.

152. Silverdale MA, Kobylecki C, Hallett PJ, Li Q, Dunah AW, Ravenscroft P, Bezard E, Brotchie JM: Synaptic recruitment of AMPA glutamate receptor subunits in levodopa-induced dyskinesia in the MPTP-lesioned nonhuman primate. Synapse 2010, 64:177-180.

153. Troiano AR, de la Fuente-Fernandez R, Sossi V, Schulzer M, Mak E, Ruth TJ, Stoessl AJ: PET demonstrates reduced dopamine transporter expression in PD with dyskinesias. Neurology 2009, 72:1211-1216.

154. Schrag A, Quinn N: Dyskinesias and motor fluctuations in Parkinson's disease. A community-based study. Brain 2000, 123:2297-2305.

155. Sharma JC, Macnamara L, Hasoon M, Vassallo M, Ross I: Cascade of levodopa dose and weight-related dyskinesia in Parkinson's disease (LDWD-PD cascade). Parkinsonism Relat Disord 2006, 12:499-505. 
156. Bachmann CG, Trenkwalder C: Body weight in patients with Parkinson's disease. Mov Disord 2006, 21:1824-1830.

157. Guigoni C, Bezard E: Involvement of canonical and non-canonical D1 dopamine receptor signalling pathways in L-DOPA-induced dyskinesia. Parkinsonism Relat Disord 2009, 15(Suppl 3):S64-67.

158. Berthet A, Porras G, Doudnikoff E, Stark H, Cador M, Bezard E, Bloch B: Pharmacological analysis demonstrates dramatic alteration of D1 dopamine receptor neuronal distribution in the rat analog of L-DOPAinduced dyskinesia. J Neurosci 2009, 29:4829-4835.

159. Fahn S: A new look at levodopa based on the ELLDOPA study. J Neural Transm Supp/ 2006, 419-426.

160. Fahn S: Parkinson disease, the effect of levodopa, and the ELLDOPA trial. Earlier vs Later L-DOPA. Arch Neurol 1999, 56:529-535.

161. Aubert I, Guigoni C, Hakansson K, Li Q, Dovero S, Barthe N, Bioulac BH, Gross CE, Fisone G, Bloch B, Bezard E: Increased D1 dopamine receptor signaling in levodopa-induced dyskinesia. Ann Neurol 2005, 57:17-26.

162. Cenci MA: Dopamine dysregulation of movement control in L-DOPAinduced dyskinesia. Trends Neurosci 2007, 30:236-243.

163. Bedard PJ, Mancilla BG, Blanchette P, Gagnon C, Di Paolo T: Levodopainduced dyskinesia: facts and fancy. What does the MPTP monkey model tell us? Can J Neurol Sci 1992, 19(1 Suppl):134-137.

164. Carta AR, Tronci E, Pinna A, Morelli M: Different responsiveness of striatonigral and striatopallidal neurons to L-DOPA after a subchronic intermittent L-DOPA treatment. Eur J Neurosci 2005, 21:1196-1204.

165. Venton BJ, Zhang H, Garris PA, Phillips PE, Sulzer D, Wightman RM: Realtime decoding of dopamine concentration changes in the caudateputamen during tonic and phasic firing. J Neurochem 2003, 87:1284-1295.

166. Tedroff J, Pedersen M, Aquilonius SM, Hartvig P, Jacobsson G, Langstrom B: Levodopa-induced changes in synaptic dopamine in patients with Parkinson's disease as measured by [11C]raclopride displacement and PET. Neurology 1996, 46:1430-1436.

167. de la Fuente-Fernandez R, Sossi V, Huang Z, Furtado S, Lu JQ, Calne DB, Ruth TJ, Stoessl AJ: Levodopa-induced changes in synaptic dopamine levels increase with progression of Parkinson's disease: implications for dyskinesias. Brain 2004, 127:2747-2754.

168. Goulet M, Morissette M, Calon F, Blanchet PJ, Falardeau P, Bedard PJ, Di Paolo T: Continuous or pulsatile chronic D2 dopamine receptor agonist (U91356A) treatment of drug-naive 4-phenyl-1,2,3,6-tetrahydropyridine monkeys differentially regulates brain D1 and D2 receptor expression: in situ hybridization histochemical analysis. Neuroscience 1997, 79:497-507.

169. Morissette M, Goulet M, Soghomonian JJ, Blanchet PJ, Calon F, Bedard PJ, Di Paolo T: Preproenkephalin mRNA expression in the caudate-putamen of MPTP monkeys after chronic treatment with the D2 agonist U91356A in continuous or intermittent mode of administration: comparison with L-DOPA therapy. Brain Res Mol Brain Res 1997, 49:55-62.

170. Lavoie B, Parent A: Immunohistochemical study of the serotoninergic innervation of the basal ganglia in the squirrel monkey. J Comp Neurol 1990, 299:1-16

171. Arai R, Karasawa N, Geffard M, Nagatsu I: L-DOPA is converted to dopamine in serotonergic fibers of the striatum of the rat: a doublelabeling immunofluorescence study. Neurosci Lett 1995, 195:195-198.

172. Carta M, Carlsson T, Kirik D, Bjorklund A: Dopamine released from 5-HT terminals is the cause of L-DOPA-induced dyskinesia in parkinsonian rats. Brain 2007, 130:1819-1833.

173. Rylander D, Parent M, O'Sullivan SS, Dovero S, Lees AJ, Bezard E, Descarries L, Cenci MA: Maladaptive plasticity of serotonin axon terminals in levodopa-induced dyskinesia. Ann Neurol 2010, 68:619-628.

174. Guigoni C, Doudnikoff E, Li Q, Bloch B, Bezard E: Altered D(1) dopamine receptor trafficking in parkinsonian and dyskinetic non-human primates. Neurobiol Dis 2007, 26:452-463.

175. Gerfen CR, Miyachi S, Paletzki R, Brown P: D1 dopamine receptor supersensitivity in the dopamine-depleted striatum results from a switch in the regulation of ERK1/2/MAP kinase. J Neurosci 2002, 22:5042-5054.

176. Oh JD, Russell DS, Vaughan CL, Chase TN: Enhanced tyrosine phosphorylation of striatal NMDA receptor subunits: effect of dopaminergic denervation and L-DOPA administration. Brain Res 1998, 813:150-159.

177. Chase TN, Oh JD: Striatal dopamine- and glutamate-mediated dysregulation in experimental parkinsonism. Trends Neurosci 2000, 23(10 Suppl):S86-91.

178. Rylander D, Iderberg H, Li Q, Dekundy A, Zhang J, Li H, Baishen R, Danysz W, Bezard E, Cenci MA: A mGluR5 antagonist under clinical development improves L-DOPA-induced dyskinesia in parkinsonian rats and monkeys. Neurobiol Dis 2010, 39:352-361.

179. Rylander D, Recchia A, Mela F, Dekundy A, Danysz W, Cenci MA: Pharmacological modulation of glutamate transmission in a rat model of L-DOPA-induced dyskinesia: effects on motor behavior and striatal nuclear signaling. J Pharmacol Exp Ther 2009, 330:227-235.

180. Mela F, Marti M, Dekundy A, Danysz W, Morari M, Cenci MA: Antagonism of metabotropic glutamate receptor type 5 attenuates L-DOPA-induced dyskinesia and its molecular and neurochemical correlates in a rat model of Parkinson's disease. J Neurochem 2007, 101:483-497.

181. Levandis G, Bazzini E, Armentero MT, Nappi G, Blandini F: Systemic administration of an mGluR5 antagonist, but not unilateral subthalamic lesion, counteracts L-DOPA-induced dyskinesias in a rodent model of Parkinson's disease. Neurobiol Dis 2008, 29:161-168.

182. Ohlin KE, Francardo V, Lindgren HS, Sillivan SE, O'Sullivan SS, Luksik AS, Vassoler FM, Lees AJ, Konradi C, Cenci MA: Vascular endothelial growth factor is upregulated by L-DOPA in the parkinsonian brain: implications for the development of dyskinesia. Brain 2011, 134:2339-2357.

183. Fredduzzi S, Moratalla R, Monopoli A, Cuellar B, Xu K, Ongini E, Impagnatiello F, Schwarzschild MA, Chen JF: Persistent behavioral sensitization to chronic L-DOPA requires $\mathrm{A} 2 \mathrm{~A}$ adenosine receptors. J Neurosci 2002, 22:1054-1062.

184. Xiao D, Bastia E, Xu YH, Benn CL, Cha JH, Peterson TS, Chen JF, Schwarzschild MA: Forebrain adenosine A2A receptors contribute to L3,4-dihydroxyphenylalanine-induced dyskinesia in hemiparkinsonian mice. J Neurosci 2006, 26:13548-13555

185. Xiao D, Cassin JJ, Healy B, Burdett TC, Chen JF, Fredholm BB, Schwarzschild MA: Deletion of adenosine $A(1)$ or $A((2) A)$ receptors reduces L-3,4-dihydroxyphenylalanine-induced dyskinesia in a model of Parkinson's disease. Brain Res 2011, 1367:310-318.

186. Bibbiani F, Oh JD, Petzer JP, Castagnoli N Jr, Chen JF, Schwarzschild MA, Chase TN: A2A antagonist prevents dopamine agonist-induced motor complications in animal models of Parkinson's disease. Exp Neurol 2003 184:285-294

187. Zeng BY, Pearce RK, MacKenzie GM, Jenner P: Alterations in preproenkephalin and adenosine-2a receptor mRNA, but not preprotachykinin mRNA correlate with occurrence of dyskinesia in normal monkeys chronically treated with L-DOPA. Eur J Neurosci 2000, 12:1096-1104.

188. Calon F, Dridi M, Hornykiewicz O, Bedard PJ, Rajput AH, Di Paolo T: Increased adenosine A2A receptors in the brain of Parkinson's disease patients with dyskinesias. Brain 2004, 127:1075-1084.

189. Ochi M, Shiozaki S, Kase H: Adenosine $A(2 A)$ receptor-mediated modulation of GABA and glutamate release in the output regions of the basal ganglia in a rodent model of Parkinson's disease. Neuroscience 2004, 127:223-231.

190. Mela F, Marti M, Bido S, Cenci MA, Morari M: In vivo evidence for a differential contribution of striatal and nigral D1 and D2 receptors to LDOPA induced dyskinesia and the accompanying surge of nigral amino acid levels. Neurobiol Dis 2012, 45:573-582.

191. Robelet S, Melon C, Guillet B, Salin P, Kerkerian-Le Goff L: Chronic L-DOPA treatment increases extracellular glutamate levels and GLT1 expression in the basal ganglia in a rat model of Parkinson's disease. Eur J Neurosci 2004, 20:1255-1266.

192. Boulet S, Lacombe E, Carcenac C, Feuerstein C, Sgambato-Faure V, Poupard A, Savasta M: Subthalamic stimulation-induced forelimb dyskinesias are linked to an increase in glutamate levels in the substantia nigra pars reticulata. J Neurosci 2006, 26:10768-10776.

193. Dupre KB, Ostock CY, Eskow Jaunarajs KL, Button T, Savage LM, Wolf W, Bishop C: Local modulation of striatal glutamate efflux by serotonin $1 \mathrm{~A}$ receptor stimulation in dyskinetic, hemiparkinsonian rats. Exp Neurol 2011, 229:288-299.

194. Konradi C, Westin JE, Carta M, Eaton ME, Kuter K, Dekundy A, Lundblad M Cenci MA: Transcriptome analysis in a rat model of L-DOPA-induced dyskinesia. Neurobiol Dis 2004, 17:219-236.

195. Rico AJ, Barroso-Chinea P, Conte-Perales L, Roda E, Gomez-Bautista V, Gendive M, Obeso JA, Lanciego JL: A direct projection from the subthalamic nucleus to the ventral thalamus in monkeys. Neurobiol Dis 2010, 39:381-392.

196. Lieu CA, Subramanian T: The interhemispheric connections of the striatum: Implications for Parkinson's disease and drug-induced dyskinesias. Brain Res Bull 2012, 87:1-9. 
197. Lieu CA, Deogaonkar M, Bakay RA, Subramanian T: Dyskinesias do not develop after chronic intermittent levodopa therapy in clinically hemiparkinsonian rhesus monkeys. Parkinsonism Relat Disord 2011 17:34-39.

198. Van Gerpen JA, Kumar N, Bower JH, Weigand S, Ahlskog JE: Levodopaassociated dyskinesia risk among Parkinson disease patients in Olmsted County, Minnesota, 1976-1990. Arch Neurol 2006, 63:205-209.

199. Biglan K, Holloway RG: Initial treatment of early Parkinson's disease: a review of recent, randomized controlled trials. Curr Neurol Neurosci Rep 2001, 1:329-336.

200. Olanow CW, Rascol O, Hauser R, Feigin PD, Jankovic J, Lang A, Langston W, Melamed E, Poewe W, Stocchi F, Tolosa E, ADAGIO Study Investigators: A double-blind, delayed-start trial of rasagiline in Parkinson's disease. N Engl J Med 2009, 361:1268-1278.

201. Samanta J, Hauser RA: Duodenal levodopa infusion for the treatment of Parkinson's disease. Expert Opin Pharmacother 2007, 8:657-664.

202. Cedarbaum JM: The promise and limitations of controlled-release oral levodopa administration. Clin Neuropharmacol 1989, 12:147-166.

203. Manson AJ, Turner K, Lees AJ: Apomorphine monotherapy in the treatment of refractory motor complications of Parkinson's disease: long-term follow-up study of 64 patients. Mov Disord 2002, 17:1235-1241

204. Nutt JG, Obeso JA, Stocchi F: Continuous dopamine-receptor stimulation in advanced Parkinson's disease. Trends Neurosci 2000, 23(10 Suppl): S109-115.

205. Olanow CW, Obeso JA, Stocchi F: Continuous dopamine-receptor treatment of Parkinson's disease: scientific rationale and clinical implications. Lancet Neurol 2006, 5:677-687.

206. Nutt JG: Continuous dopaminergic stimulation: Is it the answer to the motor complications of Levodopa? Mov Disord 2007, 22:1-9.

207. Eggert K, Schrader C, Hahn M, Stamelou M, Russmann A, Dengler R, Oertel W, Odin P: Continuous jejunal levodopa infusion in patients with advanced parkinson disease: practical aspects and outcome of motor and non-motor complications. Clin Neuropharmacol 2008, 31:151-166.

208. Schmidt WJ, Lebsanft $H$, Heindl M, Gerlach M, Gruenblatt E, Riederer $P$, Mayerhofer A, Scheller DK: Continuous versus pulsatile administration of rotigotine in 6-OHDA-lesioned rats: contralateral rotations and abnormal involuntary movements. J Neural Transm 2008, 115:1385-1392.

209. Jenner P, McCreary AC, Scheller DK: Continuous drug delivery in earlyand late-stage Parkinson's disease as a strategy for avoiding dyskinesia induction and expression. J Neural Transm 2011, 118:1691-1702.

210. Katzenschlager R, Head J, Schrag A, Ben-Shlomo Y, Evans A, Lees AJ: Fourteen-year final report of the randomized PDRG-UK trial comparing three initial treatments in PD. Neurology 2008, 71:474-480.

211. Rascol O, Brooks DJ, Korczyn AD, De Deyn PP, Clarke CE, Lang AE: A fiveyear study of the incidence of dyskinesia in patients with early Parkinson's disease who were treated with ropinirole or levodopa. 056 Study Group. N Engl J Med 2000, 342:1484-1491.

212. Rinne UK, Bracco F, Chouza C, Dupont E, Gershanik O, Marti Masso JF, Montastruc JL, Marsden CD: Early treatment of Parkinson's disease with cabergoline delays the onset of motor complications. Results of a double-blind levodopa controlled trial. The PKDS009 Study Group. Drugs 1998, 55(Suppl 1):23-30.

213. Oertel WH, Wolters E, Sampaio C, Gimenez-Roldan S, Bergamasco B, Dujardin M, Grosset DG, Arnold G, Leenders KL, Hundemer HP, Lledó A, Wood A, Frewer P, Schwarz J: Pergolide versus levodopa monotherapy in early Parkinson's disease patients: The PELMOPET study. Mov Disord 2006, 21:343-353.

214. Stowe RL, Ives NJ, Clarke C, van Hilten J, Ferreira J, Hawker RJ, Shah L, Wheatley K, Gray R: Dopamine agonist therapy in early Parkinson's disease. Cochrane Database Syst Rev 2008, , 2: CD006564.

215. Potenza MN, Voon V, Weintraub D: Drug insight: impulse control disorders and dopamine therapies in Parkinson's disease. Nat Clin Pract Neurol 2007, 3:664-672.

216. Metman LV, Del Dotto P, LePoole K, Konitsiotis S, Fang J, Chase TN: Amantadine for levodopa-induced dyskinesias: a 1-year follow-up study. Arch Neurol 1999, 56:1383-1386.

217. Del Dotto P, Pavese N, Gambaccini G, Bernardini S, Metman LV, Chase TN, Bonuccelli U: Intravenous amantadine improves levadopa-induced dyskinesias: an acute double-blind placebo-controlled study. Mov Disord 2001, 16(3):515-520.
218. Luginger E, Wenning GK, Bosch S, Poewe W: Beneficial effects of amantadine on L-DOPA-induced dyskinesias in Parkinson's disease. Mov Disord 2000, 15:873-878.

219. Meltzer HY: An overview of the mechanism of action of clozapine. J Clin Psychiatry 1994, 55(Suppl B):47-52.

220. Meltzer HY, Bastani B, Ramirez L, Matsubara S: Clozapine: new research on efficacy and mechanism of action. Eur Arch Psychiatry Neurol Sci 1989, 238:332-339.

221. Miyamoto S, Duncan GE, Marx CE, Lieberman JA: Treatments for schizophrenia: a critical review of pharmacology and mechanisms of action of antipsychotic drugs. Mol Psychiatry 2005, 10:79-104.

222. Durif F, Debilly B, Galitzky M, Morand D, Viallet F, Borg M, Thobois S,

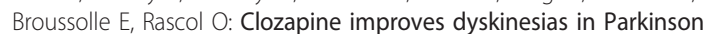
disease: a double-blind, placebo-controlled study. Neurology 2004, 62:381-388.

223. Alvir JM, Lieberman JA, Safferman AZ, Schwimmer JL, Schaaf JA: Clozapineinduced agranulocytosis. Incidence and risk factors in the United States. N Engl J Med 1993, 329:162-167.

224. Haas SJ, Hill R, Krum H, Liew D, Tonkin A, Demos L, Stephan K, McNeil J: Clozapine-associated myocarditis: a review of 116 cases of suspected myocarditis associated with the use of clozapine in Australia during 1993-2003. Drug Saf 2007, 30:47-57.

225. Evidente VG, Premkumar AP, Adler CH, Caviness JN, Driver-Dunckley E, Lyons MK: Medication dose reductions after pallidal versus subthalamic stimulation in patients with Parkinson's disease. Acta Neurol Scand 2011 124:211-214

226. Vitek JL, Bakay RA, Freeman A, Evatt M, Green J, McDonald W, Haber M, Barnhart H, Wahlay N, Triche S, Mewes K, Chockkan V, Zhang JY, DeLong MR: Randomized trial of pallidotomy versus medical therapy for Parkinson's disease. Ann Neurol 2003, 53:558-569.

227. Lewitt PA, Hauser RA, Lu M, Nicholas AP, Weiner W, Coppard N, Leinonen M, Savola JM: Randomized clinical trial of fipamezole for dyskinesia in Parkinson disease (FJORD study). Neurology 2012, 79:163-169.

228. Savola JM, Hill M, Engstrom M, Merivuori H, Wurster S, McGuire SG, Fox SH, Crossman AR, Brotchie JM: Fipamezole (JP-1730) is a potent alpha2 adrenergic receptor antagonist that reduces levodopa-induced dyskinesia in the MPTP-lesioned primate model of Parkinson's disease. Mov Disord 2003, 18:872-883.

229. Berg D, Godau J, Trenkwalder C, Eggert K, Csoti I, Storch A, Huber H, Morelli-Canelo M, Stamelou M, Ries V, Wolz M, Schneider C, Di Paolo T, Gasparini F, Hariry S, Vandemeulebroecke M, Abi-Saab W, Cooke K, Johns D, Gomez-Mancilla B: AFQ056 treatment of levodopa-induced dyskinesias: results of 2 randomized controlled trials. Mov Disord 2011, 26:1243-1250.

230. Lindsley CW, Hopkins CR: Metabotropic glutamate receptor 4 (mGlu4)positive allosteric modulators for the treatment of Parkinson's disease: historical perspective and review of the patent literature. Expert opinion on therapeutic patents 2012, 22(5):461-481.

231. Chase TN, Bibbiani F, Bara-Jimenez W, Dimitrova T, Oh-Lee JD: Translating A2A antagonist KW6002 from animal models to parkinsonian patients. Neurology 2003, 61(11 Suppl 6):S107-111.

232. Berg D, Godau J, Trenkwalder C, Eggert K, Csoti I, Storch A, Gasparini F, Hariry S, Vandemeulebroecke M, Johns D, et al: AFQ056 treatment of severe levodopa induced dyskinesias: proof of concept study. Mov Disord 2010, 25(Suppl 2):S290.

233. Baas H: Dyskinesia in Parkinson's disease. Pathophysiology and clinical risk factors. J Neurol 2000, 247(Suppl 4):IV/12-16.

234. Grandas F, Galiano ML, Tabernero C: Risk factors for levodopa-induced dyskinesias in Parkinson's disease. J Neurol 1999, 246:1127-1133.

235. Kurtzke JF, Bennett DR, Berg BO, Beringer GB, Goldstein M, Vates TS Jr: Neurologists in the United States-past, present, and future. Neurology 1986, 36:1576-1582.

236. World Health Organization, World Federation of Neurology: Atlas Country Resources for Neurological Disorders Geneva; 2004

237. Canadian Institute for Health Information: Supply, Distribution and Migration of Canadian Physicians Health Human Resources. Ottawa; 2008, 101.

238. Dorsey ER, Constantinescu R, Thompson JP, Biglan KM, Holloway RG, Kieburtz K, Marshall FJ, Ravina BM, Schifitto G, Siderowf A, Tanner CM: Projected number of people with Parkinson disease in the most populous nations, 2005 through 2030. Neurology 2007, 68:384-386. 
239. Guttman M, Slaughter PM, Theriault ME, DeBoer DP, Naylor CD: Parkinsonism in Ontario: physician utilization. Can J Neurol Sci 2002, 29:221-226.

240. Duncan RP, Earhart GM: Measuring participation in individuals with Parkinson disease: relationships with disease severity, quality of life, and mobility. Disability and rehabilitation 2011, 33:1440-1446.

241. Greene SM, Griffin WA: Symptom study in context: effects of marital quality on signs of Parkinson's disease during patient-spouse interaction. Psychiatry 1998, 61:35-45.

242. Garland B: The psychosocial impact of late-stage Parkinson's disease. J Neurosci Nurs 2004, 36:184.

243. Calne SM: The psychosocial impact of late-stage Parkinson's disease. J Neurosci Nurs 2003, 35:306-313.

244. Marras C, Lang A, Krahn M, Tomlinson G, Naglie G: Quality of life in early Parkinson's disease: impact of dyskinesias and motor fluctuations. Mov Disord 2004, 19:22-28.

245. Zach M, Friedman A, Slawek J, Derejko M: Quality of life in Polish patients with long-lasting Parkinson's disease. Mov Disord 2004, 19:667-672.

246. Hely MA, Morris JG, Reid WG, Trafficante R: Sydney Multicenter Study of Parkinson's disease: non-L-DOPA-responsive problems dominate at 15 years. Mov Disord 2005, 20:190-199.

247. Hung SW, Adeli GM, Arenovich T, Fox SH, Lang AE: Patient perception of dyskinesia in Parkinson's disease. J Neurol Neurosurg Psychiatry 2010, 81:1112-1115.

248. Jenkinson PM, Edelstyn NM, Stephens R, Ellis SJ: Why are some Parkinson disease patients unaware of their dyskinesias? Cogn Behav Neurol 2009, 22:117-121.

249. Soh SE, Morris ME, McGinley JL: Determinants of health-related quality of life in Parkinson's disease: a systematic review. Parkinsonism Relat Disord 2011, 17:1-9.

250. Winter $Y$, von Campenhausen S, Arend M, Longo K, Boetzel K, Eggert K, Oertel WH, Dodel R, Barone P: Health-related quality of life and its determinants in Parkinson's disease: results of an Italian cohort study. Parkinsonism Relat Disord 2011, 17:265-269.

251. Rahman S, Griffin HJ, Quinn NP, Jahanshahi M: Quality of life in Parkinson's disease: the relative importance of the symptoms. Mov Disord 2008, 23:1428-1434.

252. Muller T, Russ H: Levodopa, motor fluctuations and dyskinesia in Parkinson's disease. Expert Opin Pharmacother 2006, 7:1715-1730.

253. Montel S, Bonnet AM, Bungener C: Quality of life in relation to mood, coping strategies, and dyskinesia in Parkinson's disease. J Geriatr Psychiatry Neurol 2009, 22:95-102

254. Damiano AM, McGrath MM, Willian MK, Snyder CF, LeWitt PA, Reyes PF, Richter RR, Means ED: Evaluation of a measurement strategy for Parkinson's disease: assessing patient health-related quality of life. Qual Life Res 2000, 9:87-100.

255. Chapuis S, Ouchchane L, Metz O, Gerbaud L, Durif F: Impact of the motor complications of Parkinson's disease on the quality of life. Mov Disord 2005, 20:224-230.

256. Ashburn A, Stack E, Pickering RM, Ward CD: A community-dwelling sample of people with Parkinson's disease: characteristics of fallers and nonfallers. Age Ageing 2001, 30:47-52.

257. Stevenson JK, Talebifard P, Ty E, Oishi MM, McKeown MJ: Dyskinetic Parkinson's disease patients demonstrate motor abnormalities off medication. Exp Brain Res 2011, 214:471-479.

258. Marinus J, Leentjens AF, Visser M, Stiggelbout AM, van Hilten JJ: Evaluation of the hospital anxiety and depression scale in patients with Parkinson's disease. Clin Neuropharmacol 2002, 25:318-324.

259. Marinus J, Visser M, Martinez-Martin P, van Hilten JJ, Stiggelbout AM: A short psychosocial questionnaire for patients with Parkinson's disease: the SCOPA-PS. J Clin Epidemiol 2003, 56:61-67.

260. Pechevis M, Clarke CE, Vieregge P, Khoshnood B, Deschaseaux-Voinet C, Berdeaux G, Ziegler M: Effects of dyskinesias in Parkinson's disease on quality of life and health-related costs: a prospective European study. Eur J Neurol 2005, 12:956-963.

261. Dissanayaka NN, Sellbach A, Matheson S, O'Sullivan JD, Silburn PA, Byrne GJ, Marsh R, Mellick GD: Anxiety disorders in Parkinson's disease: prevalence and risk factors. Mov Disord 2010, 25:838-845.

262. Menza MA, Sage J, Marshall E, Cody R, Duvoisin R: Mood changes and "onoff" phenomena in Parkinson's disease. Mov Disord 1990, 5:148-151.
263. Henderson R, Kurlan R, Kersun JM, Como P: Preliminary examination of the comorbidity of anxiety and depression in Parkinson's disease. J Nneuropsychiatry Clini Neurosci 1992, 4:257-264.

264. Vazquez A, Jimenez-Jimenez FJ, Garcia-Ruiz P, Garcia-Urra D: "Panic attacks" in Parkinson's disease. A long-term complication of levodopa therapy. Acta Neurol Scand 1993, 87:14-18.

265. Puente V, De Fabregues O, Oliveras C, Ribera G, Pont-Sunyer C, Vivanco R, Cucurella G, Giralt E, Delgado T, Garcia C, Seoane A, Campo R: Eighteen month study of continuous intraduodenal levodopa infusion in patients with advanced Parkinson's disease: impact on control of fluctuations and quality of life. Parkinsonism Relat Disord 2010, 16:218-221.

266. Rodrigues JP, Walters SE, Watson P, Stell R, Mastaglia FL: Globus pallidus stimulation improves both motor and nonmotor aspects of quality of life in advanced Parkinson's disease. Mov Disord 2007, 22:1866-1870.

267. Happe S, Berger K: The association between caregiver burden and sleep disturbances in partners of patients with Parkinson's disease. Age Ageing 2002, 31:349-354.

268. Aarsland D, Larsen JP, Karlsen K, Lim NG, Tandberg E: Mental symptoms in Parkinson's disease are important contributors to caregiver distress. Int J Geriatr Psychiatry 1999, 14:866-874.

269. Berry RA, Murphy JF: Well-being of caregivers of spouses with Parkinson's disease. Clin Nurs Res 1995, 4:373-386.

270. O'Reilly F, Finnan F, Allwright S, Smith GD, Ben-Shlomo Y: The effects of caring for a spouse with Parkinson's disease on social, psychological and physical well-being. Br J Gen Pract 1996, 46:507-512.

271. McCabe MP, Firth L, O'Connor E: A comparison of mood and quality of life among people with progressive neurological illnesses and their caregivers. J Clin Psychol Med Settings 2009, 16:355-362.

272. Gallagher D, Rose J, Rivera P, Lovett S, Thompson LW: Prevalence of depression in family caregivers. Gerontologist 1989, 29:449-456.

273. O'Connor EJ, McCabe MP: Predictors of quality of life in carers for people with a progressive neurological illness: a longitudinal study. Qual Life Res 2011, 20:703-711.

274. A'Campo LE, Spliethoff-Kamminga NG, Macht M, Roos RA: Caregiver education in Parkinson's disease: formative evaluation of a standardized program in seven European countries. Qual Life Res 2010, 19:55-64.

275. Karlsen KH, Tandberg E, Arsland D, Larsen JP: Health related quality of life in Parkinson's disease: a prospective longitudinal study. J Neurol Neurosurg Psychiatry 2000, 69:584-589.

276. Maurel F, Lilliu H, Le Pen C: [Social and economic cost of L-DOPAinduced dyskinesias in patients with Parkinson's disease]. Rev Neurol (Paris) 2001, 157:507-514

277. Suh DC, Pahwa R, Mallya U: Treatment patterns and associated costs with Parkinson's disease levodopa induced dyskinesia. J Neurol Sci 2012, 319:24-31.

278. Canadian Institute for Health Information: The Burden of Neurological Diseases, Disorders and Injuries in Canada Ottawa; 2007

279. Huse DM, Schulman K, Orsini L, Castelli-Haley J, Kennedy S, Lenhart G: Burden of illness in Parkinson's disease. Mov Disord 2005, 20:1449-1454.

280. Wang G, Cheng Q, Zheng R, Tan YY, Sun XK, Zhou HY, Ye XL, Wang Y, Wang Z, Sun BM, Chen SD: Economic burden of Parkinson's disease in a developing country: a retrospective cost analysis in Shanghai, China. Mov Disord 2006, 21:1439-1443.

281. Haycox A, Armand C, Murteira S, Cochran J, Francois C: Cost effectiveness of rasagiline and pramipexole as treatment strategies in early Parkinson's disease in the UK setting: an economic Markov model evaluation. Drugs Aging 2009, 26:791-801.

282. LePen C, Wait S, Moutard-Martin F, Dujardin M, Ziegler M: Cost of illness and disease severity in a cohort of French patients with Parkinson's disease. PharmacoEconomics 1999, 16:59-69.

283. Gottwald MD, Aminoff MJ: Therapies for dopaminergic-induced dyskinesias in Parkinson disease. Ann Neurol 2011, 69:919-927.

284. Olanow CW, Watts RL, Koller WC: An algorithm (decision tree) for the management of Parkinson's disease (2001): treatment guidelines. Neurology 2001, 56(Suppl 5):S1-S88.

285. Goetz CG, Nutt JG, Stebbins GT: The Unified Dyskinesia Rating Scale: presentation and clinimetric profile. Mov Disord 2008, 23:2398-2403.

286. Goetz CG, Stebbins GT, Theeuwes A, Stocchi F, Ferreira JJ, van de Witte S, Bronzova J: Temporal stability of the Unified Dyskinesia Rating Scale. Mov Disord 2011, 26:2556-2559. 
287. Hagell P, Widner H: Clinical rating of dyskinesias in Parkinson's disease: use and reliability of a new rating scale. Mov Disord 1999, 14:448-455.

288. Colosimo C, Martinez-Martin P, Fabbrini G, Hauser RA, Merello M, Miyasaki J, Poewe W, Sampaio C, Rascol O, Stebbins GT, Schrag A, Goetz CG: Task force report on scales to assess dyskinesia in Parkinson's disease: critique and recommendations. Mov Disord 2010, 25:1131-1142.

289. Katzenschlager R, Schrag A, Evans A, Manson A, Carroll CB, Ottaviani D, Lees AJ, Hobart J: Quantifying the impact of dyskinesias in PD: the PDYS26: a patient-based outcome measure. Neurology 2007, 69:555-563.

290. Fenney A, Jog MS, Duval C: Bradykinesia is not a "systematic" feature of adult-onset Huntington's disease; implications for basal ganglia pathophysiology. Brain Res 2008, 1193:67-75.

291. Duval C, Fenney A, Jog MS: The dynamic relationship between voluntary and involuntary motor behaviors in patients with movement disorders. In The Basal Ganglia IX. Volume 58. Edited by: Groenewegen HJ, Berendse HW, Cools AR, Voorn P, Mulder AB. Springer; New York; 2009:521-534, Advances in Biology.

292. Duval C, Panisset M, Sadikot AF: The relationship between physiological tremor and the performance of rapid alternating movements in healthy elderly subjects. Exp Brain Res 2001, 139:412-418.

293. Lemieux S, Ghassemi M, Jog M, Edwards R, Duval C: The influence of levodopa-induced dyskinesias on manual tracking in patients with Parkinson's disease. Exp Brain Res 2007, 176:465-475.

294. Duval C: Rest and postural tremors in patients with Parkinson's disease. Brain Res Bull 2006, 70:44-48.

295. Duval C, Sadikot AF, Panisset M: The detection of tremor during slow alternating movements performed by patients with early Parkinson's disease. Exp Brain Res 2004, 154:395-398.

296. Ghassemi M, Lemieux S, Jog M, Edwards R, Duval C: Bradykinesia in patients with Parkinson's disease having levodopa-induced dyskinesias. Brain Res Bull 2006, 69:512-518.

297. Duval C, Sadikot AF, Panisset M: Bradykinesia in patients with essential tremor. Brain Res 2006, 1115:213-216.

298. Wierzbicka MM, Staude G, Wolf W, Dengler R: Relationship between tremor and the onset of rapid voluntary contraction in Parkinson's disease. J Neurol Neurosurg Psychiatry 1993, 56:782-787.

299. Goodman D, Kelso JA: Exploring the functional significance of physiological tremor: a biospectroscopic approach. Exp Brain Res 1983, 49:419-431.

300. Freund $\mathrm{HJ}$, Hefter $\mathrm{H}$ : The role of basal ganglia in rhythmic movement. Adv Neurol 1993, 60:88-92.

301. Fitts PM: The information capacity of the human motor system in controlling the amplitude of movement. J Exp Psychol 1954, 47:381-391.

302. Wenzelburger R: Peak-dose dyskinesia; an acceptable price for mobility in late-stage Parkinson's disease? Clin Neurophysiol 2005, 116:1997-1998.

\section{Pre-publication history}

The pre-publication history for this paper can be accessed here: http://www.biomedcentral.com/1741-7015/11/76/prepub

doi:10.1186/1741-7015-11-76

Cite this article as: Daneault et al: Drug-induced dyskinesia in

Parkinson's disease. Should success in clinical management be a

function of improvement of motor repertoire rather than amplitude of dyskinesia? BMC Medicine 2013 11:76.

\section{Submit your next manuscript to BioMed Central and take full advantage of:}

- Convenient online submission

- Thorough peer review

- No space constraints or color figure charges

- Immediate publication on acceptance

- Inclusion in PubMed, CAS, Scopus and Google Scholar

- Research which is freely available for redistribution 